\title{
Estimating the Changes in Glaciers and Glacial Lakes in the Xixabangma Massif, Central Himalayas, between 1974 and 2018 from Multisource Remote Sensing Data
}

\author{
Yingzheng Wang ${ }^{1,2}, \mathrm{Jia} \mathrm{Li}^{1,2, *}$, Lixin $\mathrm{Wu}^{1,2}$, Lei Guo ${ }^{1,2}$, Jun $\mathrm{Hu}{ }^{1} \mathbb{D}$ and Xin Zhang ${ }^{3}$ \\ 1 School of Geosciences and Info-Physics, Central South University, Changsha 410083, China; \\ wy-zheng@outlook.com (Y.W.); wulx66@csu.edu.cn (L.W.); tristanblus@csu.edu.cn (L.G.); \\ csuhujun@csu.edu.cn (J.H.) \\ 2 Laboratory of Geohazards Perception, Cognition and Prediction, Central South University, \\ Changsha 410083, China \\ 3 Sichuan Academy of Safety Science and Technology, Chengdu 610000, China; 13952114109@163.com \\ * Correspondence: lijia20050710@csu.edu.cn; Tel.: +86-731-888-77151
}

check for updates

Citation: Wang, Y.; Li, J.; Wu, L.; Guo, L.; Hu, J.; Zhang, X. Estimating the Changes in Glaciers and Glacial

Lakes in the Xixabangma Massif, Central Himalayas, between 1974 and 2018 from Multisource Remote Sensing Data. Remote Sens. 2021, 13, 3903. https://doi.org/10.3390/ rs13193903

Academic Editor: Gareth Rees

Received: 16 August 2021

Accepted: 28 September 2021

Published: 29 September 2021

Publisher's Note: MDPI stays neutral with regard to jurisdictional claims in published maps and institutional affiliations.

Copyright: (c) 2021 by the authors. Licensee MDPI, Basel, Switzerland. This article is an open access article distributed under the terms and conditions of the Creative Commons Attribution (CC BY) license (https:// creativecommons.org/licenses/by/ $4.0 /)$.

\begin{abstract}
The continuous melting of valley glaciers can impact the water levels of glacial lakes and create glacial lake outburst floods (GLOFs). The Xixabangma massif is one of the most populated areas in the Himalayas and has suffered from multiple GLOFs. To estimate the glacier melting rate in the past four decades and analyze the outburst risk of glacial lakes in the Xixabangma massif, we determined changes in glacier mass balance, glacier area and glacial lake area based on KH-9 images, TanDEM-X images, Landsat images, SRTM DEM and ICESat-2 elevations. Our results show that, from 1974 to 2018 , the total glacier area shrank from $954.01 \mathrm{~km}^{2}$ to $752.46 \mathrm{~km}^{2}$, whereas the total glacial lake area grew from $20.90 \mathrm{~km}^{2}$ to $38.71 \mathrm{~km}^{2}$. From 1974 to 2000, 2000 to 2013 and 2013 to 2018, the region-wide glacier mass balance values were $-0.16 \mathrm{~m}$ w.e. $/ \mathrm{a},-0.31 \mathrm{~m}$ w.e. $/ \mathrm{a}$ and $-0.29 \mathrm{~m}$ w.e. $/ \mathrm{a}$, respectively. Three glacial lakes, named Gangxico, Galongco and Jialongco, respectively, expanded by $127.14 \%, 373.45 \%$ and $436.36 \%$ from 1974 to 2018 , and the mass loss rates of their parent glaciers from 2000 to 2013 increased by $81.72 \%, 122.22 \%$ and $160.00 \%$ relative to those during 1974 to 2000 . The dams of these three lakes are unstable, and their drainage valleys directly connect to a major town and its infrastructure. Due to current high-water levels, possible external events such as ice collapse, landslide, heavy rainfall and earthquakes can easily trigger GLOFs. Hence, we deemed that the Gangxico, Galongco and Jialongco glacial lakes are dangerous and require special attention.
\end{abstract}

Keywords: glacier mass balance; TanDEM-X; SRTM; KH-9; glacial lake

\section{Introduction}

The Himalayas host more than 12,000 glaciers that cover an area of approximately $33,000 \mathrm{~km}^{2}$ and store approximately $12,000 \mathrm{~km}^{3}$ of fresh water [1,2]. Abundant glacial meltwater enables the Himalayas to form large rivers, such as the Brahmaputra, the Ganges and the Indus [3]. Since the 1950s, climate warming has aggravated glacier ablation in the Himalayas [4], and many proglacial and supraglacial lakes, which are located in the upstream parts of valleys, have emerged after glaciers have experienced constant backwasting and retreating. As temperature maintains its high level, glacier mass loss will continue and more meltwater will gather in glacial lakes. Worse still, some glaciers connected to proglacial lakes will experience an accelerated retreat, leaving more space for glacial lake expansion. Consequently, water pressure over lake dams will increase, leading to the potential hazard of dam bursts. Hence, glacier mass loss can directly affect the stability of a glacial lake, so the quantitative estimation of glacier mass balance can help to assess the hazard of glacial lake outbursts [5]. At present, glacier mass balance can be measured in several ways, including in situ measurements (e.g., stake records, differential global 
position system) [6], geodetic measurements (i.e., glacier surface elevation differencing) [7] and gravimetry measurements [8]. Geodetic measurements based on DEMs have a fine resolution and wide coverage, and are thus suitable for estimating basin- or region-wide glacier mass balance.

Many efforts are being implemented regarding geodetic glacier mass balance results in the Himalayas (Table 1). When sorting these results, we found that previous geodetic glacier mass balance studies were essentially conducted in four regions, i.e., the western SpitiLahaul region (Western Himalayas), the Bhutan-China border region (Eastern Himalayas), the central Langtang regions and the Everest region (Central Himalayas) (Figure 1). These regions are far apart and controlled by different climate patterns. In particular, the western, central and eastern Himalayas are mainly controlled by the Westerlies, the Indian Summer monsoon and the East Asian monsoon, respectively [9]. Previous studies have revealed that different climate conditions are the main reason for the macroscopic spatial heterogeneity of glacier mass balance in the Himalayas [10], while local differences are caused by terrain, debris cover, ice cliffs and glacial lakes [11-13]. However, these studies rarely covered glacier mass balance in the Xixabangma massif, especially over the past 40 years, and seldom analyzed the impact of glacier mass changes on glacial lake stability. The Xixabangma massif in the Central Himalayas is host to a large human population. Documents show that GLOFs have occurred multiple times in this region [14,15]. In June 1995, Zhanapo lake burst, causing traffic jams and house damage in Gyirong county [14]; in the summer of 2002, Jialongco lake burst twice, triggering floods and debris flow that caused devastating damage to bridges, houses and farmland in Nyalam County, as well as the China-Nepal Highway [15]. Moreover, previous studies have given a detailed introduction to the mechanisms and hazards of glacial lake outbursts in the Xixabangma massif [15-17], but none of them have examined quantitative glacier mass balance.

Table 1. Geodetic glacier mass balance measurements in the Himalayas.

\begin{tabular}{|c|c|c|c|c|c|}
\hline Reference & Location & $\begin{array}{c}\text { Glacier Area } \\
\left(\mathrm{km}^{2}\right)\end{array}$ & Data & Period & $\begin{array}{c}\text { Mass Balance } \\
\text { (m w.e./a) }\end{array}$ \\
\hline [1] & Spiti-Lahaul & 608.8 & SRTM-C DEM-SPOT5 DEM & 1999-2004 & $-0.7 \sim-0.85$ \\
\hline [18] & Chhota-Shigri & 15.7 & SRTM-C DEM-SPOT5 DEM & 1999-2011 & $-0.39 \pm 0.15$ \\
\hline \multirow{2}{*}{ [19] } & \multirow{2}{*}{ Chhota-Shigri } & \multirow{2}{*}{15.5} & Field Measurements-SPOT5 DEM & $2002-2014$ & $-0.56 \pm 0.40$ \\
\hline & & & Pleiades DEM-SPOT5 DEM & 2005-2014 & $-0.34 \pm 0.24$ \\
\hline [20] & Spiti-Lahaul & 1711.9 & SRTM-C DEM-TanDEM-X DEM & 2000-2012 & $-0.53 \pm 0.37$ \\
\hline \multirow{2}{*}[21]{} & \multirow{2}{*}{ Spiti-Lahaul } & \multirow{2}{*}{350.3} & KH-4B DEM-SRTM-C DEM & 1971-1999 & $-0.07 \pm 0.10$ \\
\hline & & & SRTM-C DEM-ASTER/Cartosat-1 DEM & After 2000 & $-0.30 \pm 0.10$ \\
\hline [22] & Bhutan & 1367.1 & SRTM-C DEM-SPOT5 DEM & 2000-2011 & $-0.22 \pm 0.13$ \\
\hline [23] & China-Bhutan & 365 & KH-9 DEM-ASTER DEM & 1974-2006 & $-0.17 \pm 0.05$ \\
\hline \multirow{2}{*}{ [24] } & \multirow{2}{*}{ Everest } & 46.9 & KH-4B DEM-Cartosat-1 DEM & 1970-2007 & $-0.32 \pm 0.08$ \\
\hline & & 49.6 & Cartosat-1 DEM-ASTER DEM & $2002-2007$ & $-0.79 \pm 0.52$ \\
\hline [22] & West Nepal & 890.4 & SRTM-C DEM-SPOT5 DEM & 2000-2011 & $-0.32 \pm 0.14$ \\
\hline [25] & Langtang & 94.9 & KH-9 DEM-SRTM-C DEM & 1974-2000 & $-0.32 \pm 0.18$ \\
\hline [26] & Kanchenjunga & 60.5 & KH-9 DEM-PRISM DEM & 1975-2010 & $-0.18 \pm 0.17$ \\
\hline$[4]$ & Everest & 706.6 & SRTM-C DEM-Worldview DEM & 2000-2015 & $-0.52 \pm 0.22$ \\
\hline [2] & Gangotri & 122 & SRTM-C DEM-Cartosat-1 DEM & 1999-2014 & $-0.55 \pm 0.42$ \\
\hline
\end{tabular}

In order to reveal the evolution of glaciers and glacial lakes in the Xixabangma massif during the past 40 years, and to analyze the risk of glacial lake outbursts based on multiple factors including glacier mass balance, we first delineated four terms related to glacier and 
glacial lake boundaries and derived geodetic glacier mass balance in three periods during 1974-2018 from multi-source remote sensing data. Then, we analyzed glaciers' responses to climate change between 1967 and 2018. Finally, the risk of glacial lake outbursts was discussed based on the expanding rates and sizes of lakes, the mass balance of parent glaciers and other current factors.

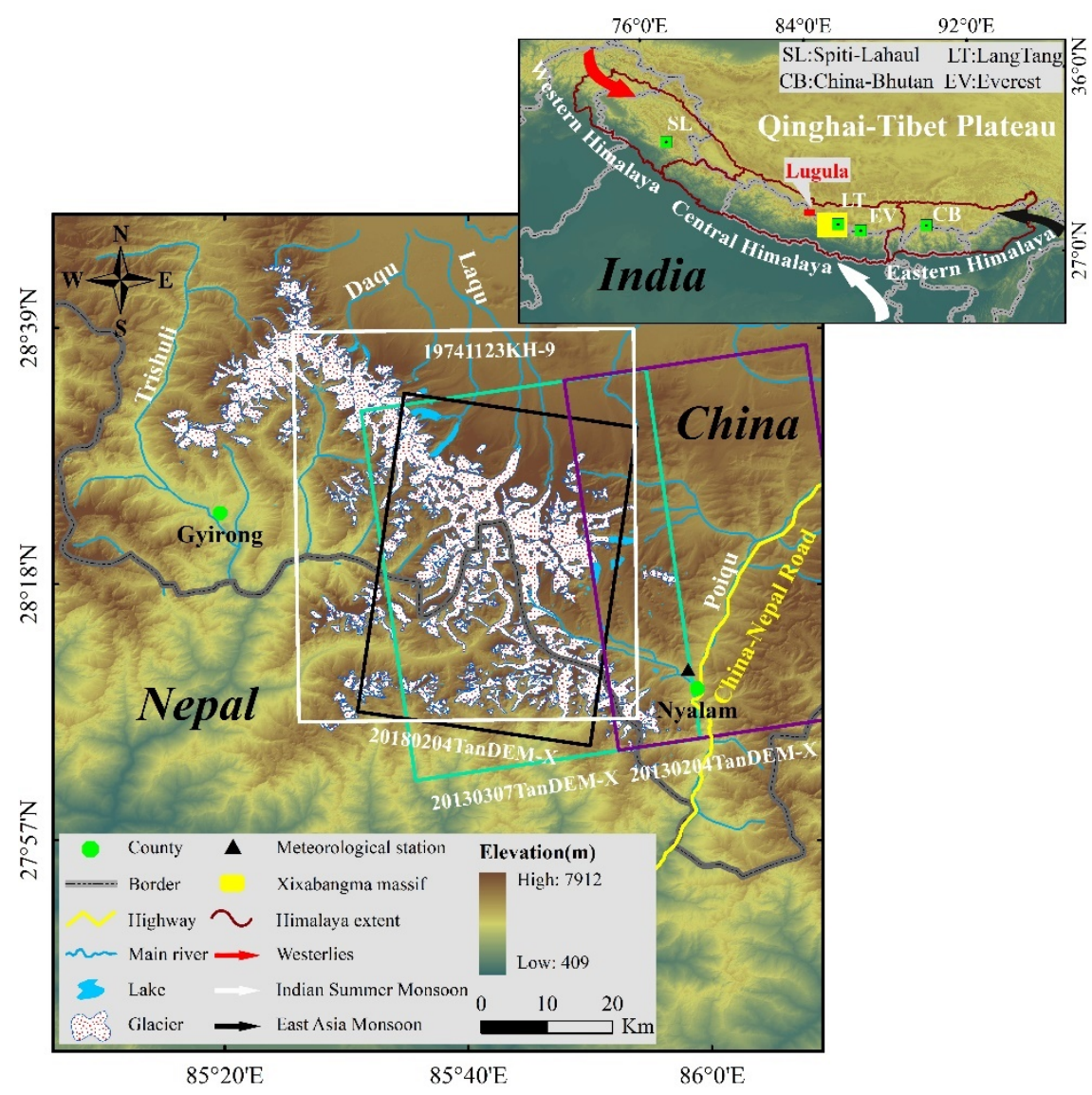

Figure 1. Distributions of glaciers and glacial lakes in the Xixabangma massif, Central Himalayas. The white rectangle denotes the coverage of the KH-9 image. The chrysoprase, black and purple rectangles denote the coverage of the TanDEM-X images acquired on different dates.

\section{Study Area}

The Xixabangma massif $\left(85^{\circ} 15^{\prime}-86^{\circ} 05^{\prime} \mathrm{E}, 28^{\circ} 05-28^{\circ} 45^{\prime} \mathrm{N}\right)$ straddles the China-Nepal border (Figure 1). Its altitude ranges from approximately $1000 \mathrm{~m}$ a.s.l. to $8000 \mathrm{~m}$ a.s.l. Influenced by the Indian monsoon and westerly circulation, the southern slope receives plentiful precipitation, and the glaciers developed there are primarily maritime in nature. Since the transport of water vapor is blocked by high mountains, the northern slope receives much less precipitation, and the glaciers developed there belong primarily to the continental type. The annual average temperature is approximately $2.1^{\circ} \mathrm{C}$, and the annual accumulated precipitation is approximately $580 \mathrm{~mm}$ [27]. Precipitation mainly occurs in summer. Many large glaciers have their tongues covered by debris, and rivers are fed by glacier meltwater flow in the region's winding and deep-cut valleys. Proglacial moraine and outwash are abundant, and GLOFs can easily create debris flow. The resident population of the Xixabangma massif is approximately 25,000. Many infrastructures, including the China-Nepal Road, have been built in this region. This region is close to the Himalayan seismic belt, which suffers from frequent earthquakes; an earthquake up to a magnitude of 7.8 (M 7.8) occurred on 25 April 2015, and another one up to M 7.3 occurred on 12 May 2015. Both triggered considerable debris flow in China and Nepal [28]. 


\section{Datasets and Methods}

We first delineated glacier outlines and extracted DEMs from remote sensing images (Table 2) and then derived changes in glacier thickness by differentiating the DEMs of different dates and removing systematic bias in the elevation difference maps. Afterward, we computed changes in glacier mass based on glacier area, elevation change and mass density. The workflow of glacier mass balance measurement is illustrated in Figure 2. Detailed processing is introduced in the next sections.

Table 2. Data used in this study.

\begin{tabular}{|c|c|c|c|c|}
\hline Data & Date & Resolution & Product ID & Usage \\
\hline $\begin{array}{l}\text { KH-9 stereo } \\
\text { image }\end{array}$ & $23 / 11 / 1974$ & $7 \mathrm{~m}$ & $\begin{array}{l}\text { DZB1209-500101L006001 } \\
\text { DZB1209-500101L007001 }\end{array}$ & $\begin{array}{c}\text { Glacier/glacial lake outline delineation; } \\
\text { DEM extraction }\end{array}$ \\
\hline $\begin{array}{l}\text { Landsat-8 } \\
\text { OLI image }\end{array}$ & $\begin{array}{l}24 / 10 / 2018 \\
09 / 11 / 2018 \\
25 / 11 / 2018\end{array}$ & \multirow{4}{*}{$15 \mathrm{~m}$} & $\begin{array}{l}\text { LC81400412018297LGN00 } \\
\text { LC81400412018313LGN00 } \\
\text { LC81400412018329LGN00 }\end{array}$ & \multirow{2}{*}{$\begin{array}{l}\text { Glacier/glacial lake } \\
\text { outline delineation }\end{array}$} \\
\hline \multirow{3}{*}{$\begin{array}{l}\text { Landsat-7 ETM+ } \\
\text { image }\end{array}$} & $\begin{array}{l}06 / 10 / 2012 \\
22 / 10 / 2012 \\
07 / 11 / 2012\end{array}$ & & $\begin{array}{l}\text { LE71410402012280PFS00 } \\
\text { LE71410402012296PFS00 } \\
\text { LE71410402012312PFS00 }\end{array}$ & \\
\hline & $05 / 10 / 2000$ & & LE71410402000279SGS00 & \multirow[b]{2}{*}{$\begin{array}{l}\text { Glacier/glacial lake outline delineation; } \\
\text { horizontal reference for DEM extraction }\end{array}$} \\
\hline & $22 / 11 / 2000$ & & $\begin{array}{l}\text { LE71410392000327EDC00 } \\
\text { LE71410402000327EDC00 } \\
\text { LE71410412000327EDC00 }\end{array}$ & \\
\hline $\begin{array}{l}\text { Landsat-5 } \\
\text { TM image }\end{array}$ & $\begin{array}{l}13 / 10 / 2000 \\
16 / 12 / 2000\end{array}$ & $30 \mathrm{~m}$ & $\begin{array}{l}\text { LT51410402000287BKT00 } \\
\text { LT51410402000351BKT00 }\end{array}$ & Glacier/glacial lake outline delineation \\
\hline $\begin{array}{l}\text { TanDEM-X } \\
\text { CoSSC image }\end{array}$ & $\begin{array}{l}24 / 02 / 2013 \\
24 / 02 / 2018\end{array}$ & $\begin{array}{l}1.36 \mathrm{~m} \times 1.85 \mathrm{~m} \\
(\text { Range } \times \text { Azimuth })\end{array}$ & $\begin{array}{l}\text { TDM1_SAR_COS_BIST_SM_S_SRA } \\
\text { 20130307T121856_20130307T121904 } \\
\text { TDM1_SAR_COS_BIST_SM_S_SRA } \\
\text { 20130224T121856_20130224T121904 } \\
\text { TDM1_SAR_COS_BIST_SM_S_SRA } \\
\text { 20180224T001328_20180224T001335 }\end{array}$ & DEM extraction \\
\hline SRTM-C DEM & $11 / 02 / 2000$ & $30 \mathrm{~m}$ & - & $\begin{array}{l}\text { Historical elevation; horizontal reference } \\
\text { for DEM extraction }\end{array}$ \\
\hline \multirow[t]{2}{*}{$\begin{array}{l}\text { ICESat-2/ATLAS } \\
\text { ATL06 product }\end{array}$} & $\begin{array}{l}26 / 10 / 2018 \\
10 / 11 / 2018 \\
27 / 12 / 2018 \\
11 / 01 / 2019\end{array}$ & \multirow[t]{2}{*}{ Point } & $\begin{array}{l}\text { ATL06_20181026091136_04240102_002 } \\
\text { ATL06_20181110202842_06600106_002 } \\
\text { ATL06_20181227061521_13690102_002 } \\
\text { ATL06_20190111173213_02180206_002 }\end{array}$ & DEM accuracy assessment \\
\hline & $\begin{array}{l}27 / 12 / 2018 \\
09 / 02 / 2019\end{array}$ & & $\begin{array}{l}\text { ATL06_20181227061521_13690102_002 } \\
\text { ATL06_20190209160826_06600206_002 }\end{array}$ & X-band penetration depth estimation \\
\hline $\begin{array}{l}\text { Meteorological } \\
\text { data }\end{array}$ & $1967-2018$ & Station & - & Climate change \\
\hline
\end{tabular}

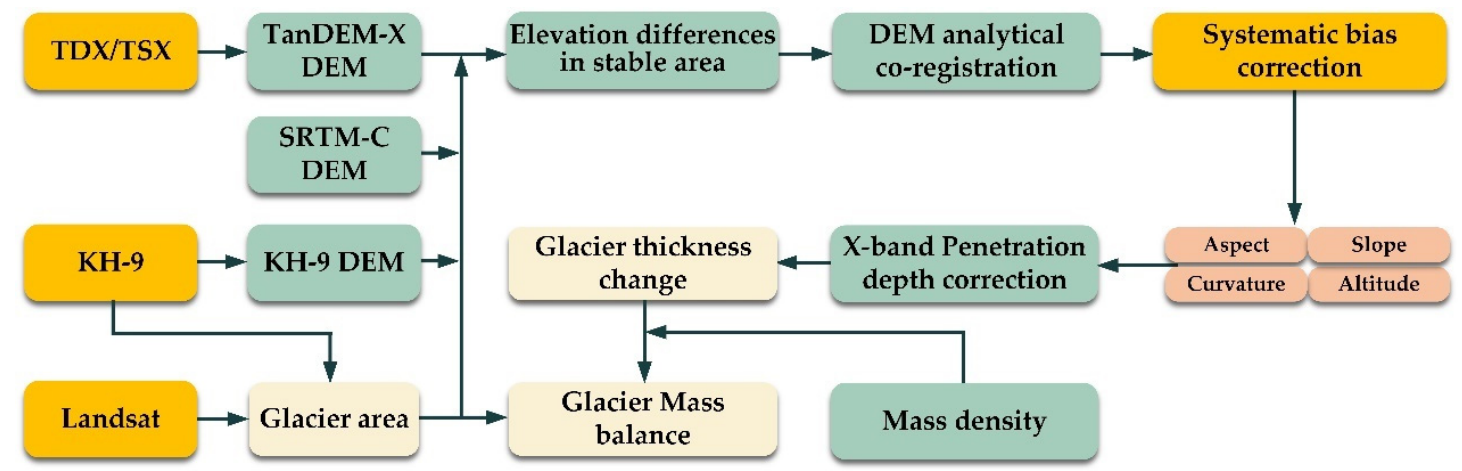

Figure 2. Workflow of glacier mass balance measurement. 


\subsection{Generation of KH-9 DEM}

Reconnaissance optical satellite Keyhole (KH-9) was on active service from 1971 to 1986. The archive images were declassified in 2002. The KH-9 images distributed by the United States Geological Survey were scanning images of the film negative taken by a framemapping camera. The metadata of KH-9 imaging are unknown. The quality of released KH-9 images is affected by pixel distortion and scratches due to their long storage time. Nevertheless, given their high spatial resolution $(6-9 \mathrm{~m})$, wide swath $(120 \times 250 \mathrm{~km})$, high forward overlapping rate $(70 \%)$ and the advantage of early acquisition time, these KH-9 images are an important data source for land-cover change detection [29]. Each KH-9 image consists of two sub-images, and each sub-image has a reseau cross alignment of $23 \times 24$. In this study, one KH-9 stereo image of 7 microns (3600 dpi) acquired on 23 November 1974 was used to generate a DEM (Table 2). To extract a DEM from a KH-9 stereo image, three steps, including pre-processing, internal orientation and external orientation, need to be performed. Image pre-processing consists of image resampling, reseau cross identification, distortion correction, sub-image mosaic and contrast enhancement [30]. Internal orientation was accomplished on the basis of the geometric model of the frame-mapping camera and parameter settings. External orientation was accomplished on the basis of external control points and tie points. The external control points were manually selected at the places of ground features, such as river confluences and giant rocks, by combining Landsat-7/ETM+ L1T images and SRTM-C DEM (in ice-free regions) [31]. The tie points were automatically generated. Finally, a KH-9 DEM with a resolution of $30 \mathrm{~m}$ was generated.

\subsection{Generation of TanDEM-X DEM}

Given their high spatial resolution, wide swath and all-weather working capability, active synthetic aperture radar (SAR) images are widely used for ground deformation monitoring and topography mapping. Shuttle Radar Topography Mission (SRTM), a famous SAR interferometry (InSAR) mission that works in a single-pass dual-antenna mode, obtained DEMs covering $80 \%$ of the global land surface within 11 days in February 2000. The German Aerospace Center launched the TerraSAR-X and TanDEM-X satellites in 2007 and 2010, respectively. These two satellites form a constellation. Under the bistatic working mode, one of the two satellites transmits signals, and two receive an echo simultaneously; therefore, master and slave images for interferometry can be obtained at the same time. The zero-temporal baseline ensures the temporal correlation of the interferometric phase. In this study, three bistatic strip map TanDEM-X image pairs acquired in 2013 and 2018 were used to generate DEMs (Table 2).

The raw interferometric phase $\left(\varphi_{\text {int }}\right)$ comprises the topographic phase $\left(\varphi_{\text {topo }}\right)$, the flat earth phase $\left(\varphi_{\text {flat }}\right)$, the displacement phase $\left(\varphi_{\text {dis }}\right)$, the atmospheric phase $\left(\varphi_{\text {atm }}\right)$ and the noise phase $\left(\varphi_{\text {noise }}\right)$ Equation (1). Given that master and slave images are acquired simultaneously, the displacement and atmospheric phase can be ignored. Most of the noise phase can be removed by multilooking and filtering, and the flat earth phase can be simulated on the basis of imaging parameters. After the removal of the noise phase and the flat earth phase, the topographic phase $\left(\varphi_{\text {topo }}\right)$ can be estimated.

$$
\varphi_{\text {int }}=\varphi_{\text {topo }}+\varphi_{\text {flat }}+\varphi_{\text {dis }}+\varphi_{\text {atm }}+\varphi_{\text {noise }}
$$

Given the short wavelength of the X-band, the fringes of TanDEM-X interferograms are dense in the mountainous region, thus making phase unwrapping difficult. To address this problem, a topographic phase was simulated from SRTM-C DEM and subtracted from the observed TanDEM-X topographic phase. The differential phase with much sparser fringes was easily unwrapped. The unwrapped phase was converted into elevation difference through the following formula:

$$
h=-\frac{\varphi_{\text {topo }} \cdot \lambda \cdot R \cdot \sin \theta_{0}}{2 \pi \cdot B_{\perp}}
$$


where $\lambda, R, \theta_{0}$ and $B_{\perp}$ are the radar wavelength, slant range, nominal incident angle and perpendicular baseline, respectively. A new DEM was obtained by adding elevation difference to the SRTM-C DEM. After backward geocoding, we finally derived the TanDEMX DEMs with a spatial resolution of $30 \mathrm{~m}$ in 2013 and 2018.

\subsection{Delineation of Glacier and Glacial Lake Outlines}

Glacier outlines are a prerequisite for calculating glacier area. Moreover, when evaluating DEM accuracy and correcting systematic bias in elevation difference maps, we need to mask the glacierized area with glacier outlines. We collected Landsat L1T images with little cloud and seasonal snow cover and conducted radiation calibration and atmospheric correction on them [32]. The initial glacier outline (Figure 3a) was extracted from the corrected Landsat images through the band ratio method (Red/SWIR) [33]. Water bodies and fresh snowpacks are generally misclassified as glaciers, and glaciers in the shadow cannot be discerned. We manually edited the glacier outlines by combining multiple images acquired in the same seasons. Regarding debris cover in the glacier ablation zone, we further manually revised the glacier boundary based on Landsat panchromatic-multispectral fused images, Google Earth high-resolution images, DEM and elevation difference maps [23].
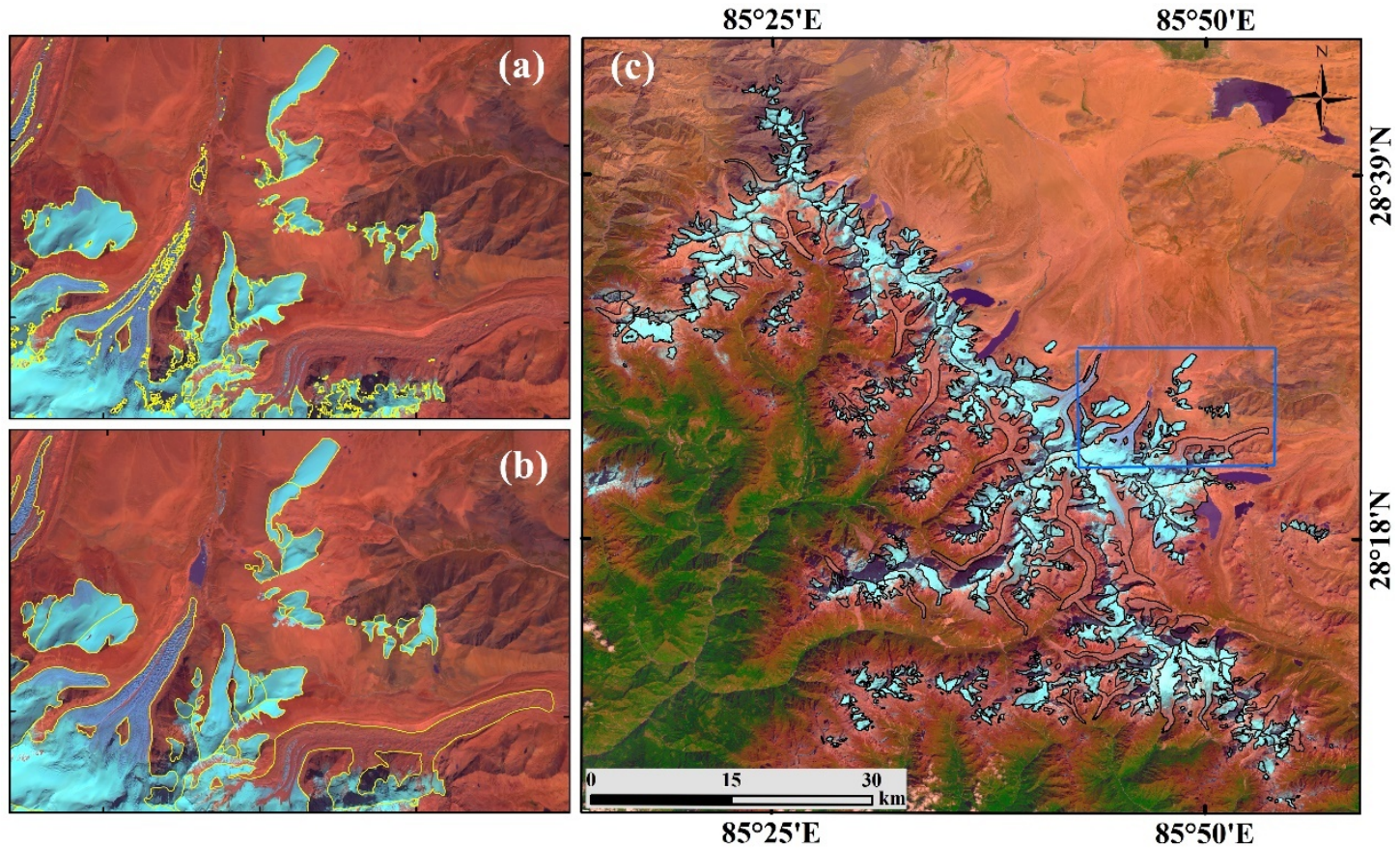

Figure 3. Subfigures $(\mathbf{a}, \mathbf{b})$, respectively, represent the automatically extracted glacier outlines and manually edited glacier outlines in 2018. Subfigure (c) is the 2018 glacier outline map of Xixabangma massif. The blue rectangle in subfigure (c) denotes the position of subfigures $(\mathbf{a}, \mathbf{b})$.

The orthorectified KH-9 images were used to extract glacier outlines in 1974. We first delineated the glacier outlines from KH-9 images through visual interpretation and then manually revised them on the basis of the elevation difference map (SRTM-C DEM-KH-9 DEM).

The boundaries of glacial lakes were first extracted through a normalized difference water index method and then manually edited through visual interpretation.

\subsection{Evaluation of DEM Accuracy}

We used ICESat-2/ATLAS ATL06 elevation products as a reference to evaluate the accuracy of DEMs generated in this study. The accuracy of the ICESat-1/GLAS elevation product in flat regions reaches $0.14 \mathrm{~m}$ [34], and the officially announced accuracy of the ICESat-2/ATLAS elevation product is higher [35]. The footprints of ICESat-2 data adopted 
in this study are shown in Figure 4f. Regarding the negative effect of steep slopes, we selected the ICESat-2 points in stable regions with a slope below 30 degrees. The DEM values at the footprints of ICESat-2 data were extracted via bilinear interpolation. Given that outliers may exist in ICESat-2 elevation products and DEMs, we set a threshold of $\pm 100 \mathrm{~m}$ for elevation difference. As shown in Figure 4, the accuracy of KH-9 DEM was lower than that of the SRTM-C DEM and TanDEM-X DEM. The root mean square error of KH-9 is $\pm 21.53 \mathrm{~m}$, whereas that for TanDEM-X and SRTM-C DEMs ranges from only $\pm 3 \mathrm{~m}$ to $\pm 7 \mathrm{~m}$. However, glacier mass balance changed greatly during the last decades of the 20th century, and the differencing of KH-9 DEM (1974) with SRTM-C (2000) or TanDEM-X (2018) DEMs can still provide valuable information regarding changes in glacier thickness.
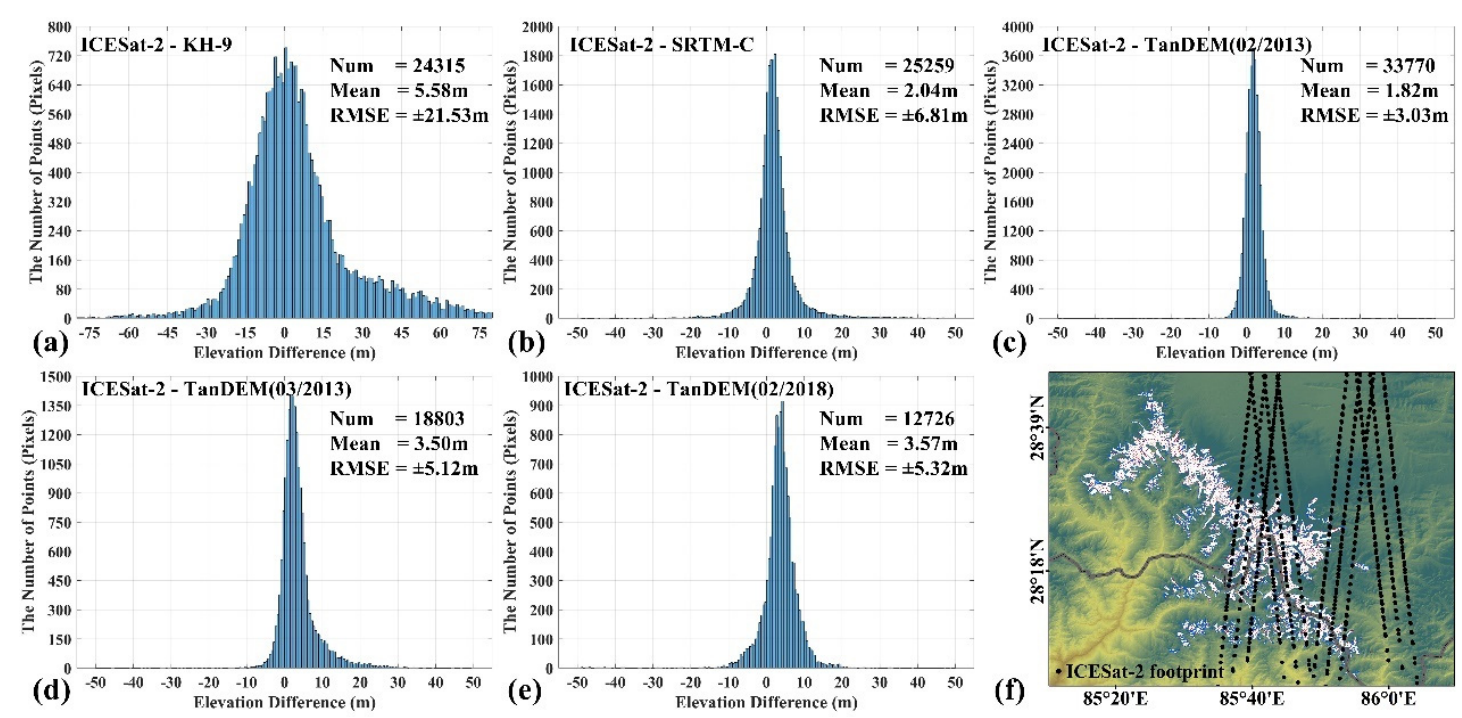

Figure 4. Results of evaluating the KH-9, SRTM-C and TanDEM-X DEMs with the ICESat-2/ATLAS ATL06 elevation product (a-e). Subfigure (f) shows the footprints of utilized ICESat-2 points.

\subsection{Estimation of Changes in Glacier Thickness}

\subsubsection{DEM Co-Registration and Systematic Error Correction}

Changes in glacier thickness were estimated by differencing DEMs at different times. Due to the different acquisition times and imaging approaches, and the different methods of DEM generation, the processed KH-9, SRTM-C and TanDEM-X DEMs have different geolocation accuracies and may cover different areas, even though they have the same geographical coordinates. Any two DEMs must be co-registered before differencing them because a tiny shift in the DEMs can cause considerable errors in elevation differences in mountainous regions. We used the analytical co-registration method proposed by Nuth and Kääb in 2011 [36]. This method is operated on the basis of terrain slope, aspect and raw elevation difference and has been proven to be robust and efficient in matching DEMs over glacierized regions. This method decomposes the DEM shift vector into vertical and horizontal components. Vertical shift is assumed to be systematic. A functional relationship is built amongst horizontal shift, terrain slope, aspect and raw elevation difference Equation (3). The shift parameters were solved on the basis of the least square principle, and the DEMs were resampled in accordance with the shift parameters. For additional details about this method, readers can refer to [36]. The distribution of normalized elevation difference (TanDEM-X DEM in 2013-RTM-C DEM in 2000) against terrain aspect before DEM co-registration is illustrated in Figure 5a.

$$
d h=a \cdot \cos (b-\varphi) \cdot \tan \alpha+Z \quad i=1,2,3, \ldots n
$$


where $d h$ is the elevation difference in stable region; $a$ is the plane shift vector; $b$ is the direction of plane shift vector; $\varphi$ is the terrain aspect; $\alpha$ is the terrain slope; $Z$ is the vertical bias.
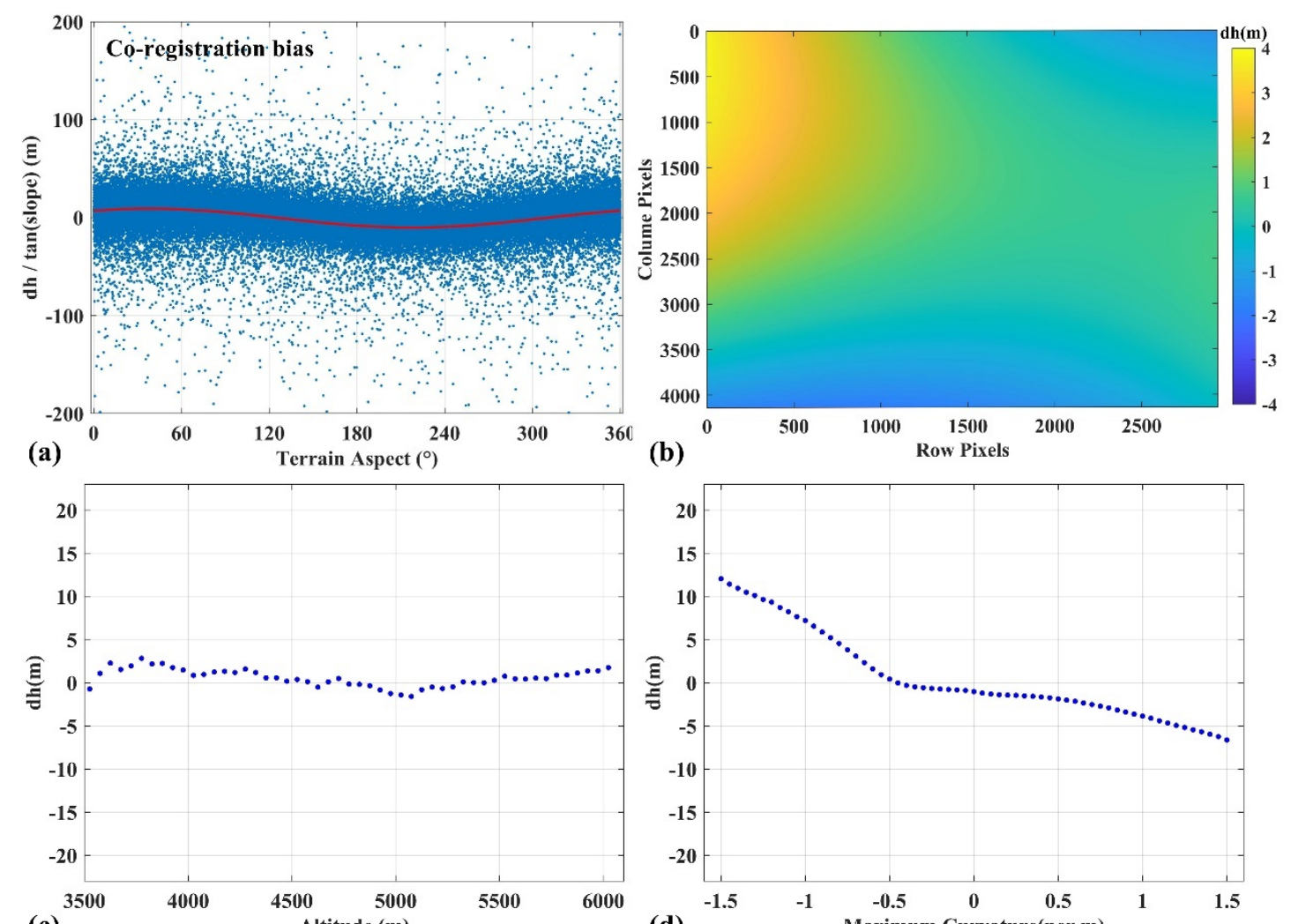

(c)

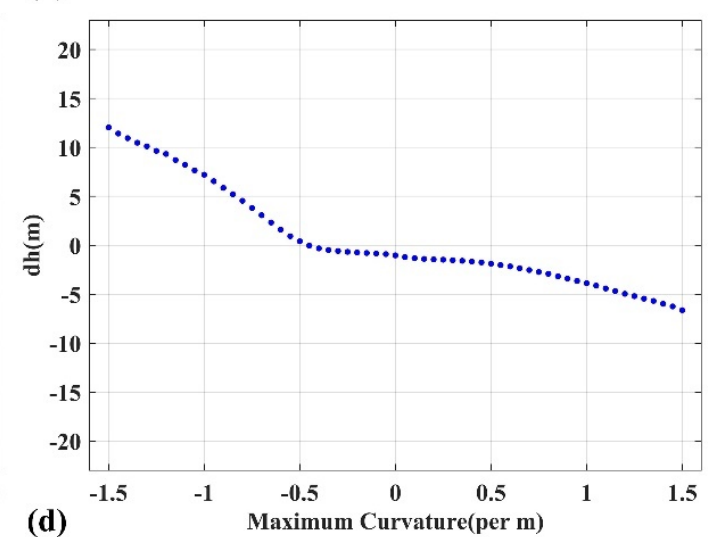

Figure 5. Universal bias trends fitted for elevation difference over stable region (TanDEM-X DEM-SRTM-C DEM). Subfigure (a) represents the distribution of normalized elevation differences over stable regions against terrain aspect before DEM co-registration. Red curves denote the regressed cosine function. Subfigures $(\mathbf{b}-\mathbf{d})$ represent the distribution of biases related to planimetric position, altitude and terrain curvature, respectively.

Elevation difference maps usually contain systematic biases that can considerably affect the result of glacier thickness change measurements [36,37]. We also found systematic biases in the elevation difference maps that were related to planimetric position, altitude and terrain maximum curvature. In particular, planimetric position-related bias may be caused by baseline residue (for InSAR DEM generation) and spatial interferometric decorrelation (for InSAR DEM generation) [36]; altitude related bias may be caused by the non-uniform distribution of external control points in altitudes (for optical DEM generation) [38] and spatial interferometric decorrelation (for InSAR DEM generation); and terrain maximum curvature bias may be caused by a resolution discrepancy between the source data of two DEMs [37,39]. Assuming the systematic biases of elevation differences over glaciers and surrounding ice-free regions are common, we fitted these systematic biases as universal trends from elevation differences in ice-free regions and removed them from the whole elevation difference maps [36]. Systematic bias related to planimetric position can be corrected by quadratic or cubic surface fitting Equation (4), and systematic biases related to altitude and terrain curvature can be corrected by quadratic or cubic polynomials Equation (5). The order $n$ depends on the distribution of bias. The magnitude of biases related to planimetric position, altitude and curvature (TanDEM-X DEM in 2013SRTM-C DEM in 2000) is illustrated in Figure 5b, $5 c$ and $5 d$, respectively.

$$
d h=a_{0}+a_{1} x+a_{2} y+a_{3} x^{2}+a_{4} x y+a_{5} y^{2}
$$




$$
d h=a_{0}+a_{1} p+a_{2} p^{2}+\ldots+a_{n} p^{n}
$$

where $d h$ is the elevation difference observation; $a_{i}$ is the model coefficient; $x$ and $y$ are the row and column number of the pixel; $p$ is the terrain parameters (altitude or terrain curvature); $n$ is the order of polynomial.

Elevation differences over stable regions are supposed to be zero; therefore, a standard deviation (STD) of observations over stable regions can describe the quality of elevation difference maps. However, STD is sensitive to outliers. We used normalized median absolute deviation (NMAD) instead, as it is less sensitive to outliers and can be considered a robust estimator of STD [31,40]. The NMAD is computed by Equation (6). Table 3 shows the NMAD and mean of elevation difference observations in stable regions before and after DEM co-registration and systematic bias corrections. The smaller the NMAD, the higher the accuracy of elevation difference observations.

$$
N M A D=1.4826 \cdot \text { median }\left(\mid \Delta h_{i}-\text { median }(\Delta h) \mid\right) \quad i=1,2,3, \ldots n
$$

where $\Delta h$ is the elevation difference observation and $n$ is the number of elevation difference observations.

Table 3. Statistical results of elevation difference in stable regions before and after DEM co-registration

\begin{tabular}{|c|c|c|c|c|c|}
\hline \multirow{2}{*}{ Period } & \multicolumn{2}{|c|}{ Raw Elevation Difference } & \multicolumn{2}{|c|}{ Corrected Elevation Difference } & \multirow{2}{*}{$\begin{array}{l}\text { Improvement } \\
\text { of NMAD }\end{array}$} \\
\hline & Mean & NMAD & Mean & NMAD & \\
\hline 1974-2000 & -1.18 & 15.63 & 0.22 & 12.17 & $22.14 \%$ \\
\hline 2000-2013 & 0.01 & 5.25 & -0.05 & 3.58 & $31.81 \%$ \\
\hline 2013-2018 & -0.47 & 3.33 & 0.01 & 2.32 & $30.33 \%$ \\
\hline
\end{tabular}
and systematic bias correction.

\subsubsection{Correction of C-Band and X-Band Penetration Effects}

The penetration of radar signals over glacier surfaces must be considered when estimating changes in glacier thickness through differencing InSAR and optical DEMs or differencing InSAR DEMs of distinct microwave bands. In theory, the absolute X-band penetration depth can be estimated by differencing the TanDEM-X elevations with the ICTSat-2/ATLAS ATL06 elevations because the penetration depth of laser signals over glacier surfaces is negligible. However, ICEsat-2 data were not available until October 2018, whereas our newest TanDEM-X data were acquired in February 2018. We assumed the elevation change between 24 February 2018 and 24 February 2019 was equal to the average annual change between 24 February 2013 and 24 February 2018; we then extrapolated the TanDEM-X glacier surface elevation on 24 February 2019. The ICESat-2/ATLAS ATL06 elevations on 27 December 2018 and 9 February 2019 were then differenced with the extrapolated TanDEM-X elevation to estimate the winter X-band penetration depth over glacier surfaces. The distinction between $\mathrm{C}$-band and $\mathrm{X}$-band penetration depths over glacier surfaces was estimated by differencing the simultaneously obtained C-band and X-band SRTM DEM. The absolute winter C-band penetration depth was then obtained by adding the above two results together. The SRTM-X DEM does not cover the glaciers in the Xixabangma massif. Regarding the similarity of climate condition, we selected the Lugula region (red area in the inset panel in Figure 1), which is adjacent to the Xixabangma massif, to estimate the difference of C-band and X-band penetration depths. Finally, we fitted the penetration depth as a function of altitude and slope and corrected the penetration effects in elevation difference maps pixel by pixel. 


\subsection{Computation of Glacier Mass Balance}

The change in glacier volume was computed through the hypsography method, and a mass density of $850 \pm 60 \mathrm{~kg} / \mathrm{m}^{3}$ was used to convert the glacier volume change into glacier mass balance [41]. The computation formula of glacier mass balance is

$$
B=\frac{\rho_{\text {glacier }}}{A \times \rho_{\text {water }}} \sum_{i=1}^{N}\left(\Delta h_{i} \times A_{i}\right)
$$

where $B, A, \rho_{\text {glacier }}$ and $\rho_{\text {water }}$ are glacier mass balance, glacier area, glacier mass density and water density $\left(1000 \mathrm{~kg} / \mathrm{m}^{3}\right)$, respectively; $N$ is the number of altitude intervals; $A_{i}$ and $\Delta h_{i}$ are the glacier area and average glacier thickness change within each altitude interval $(100 \mathrm{~m})$, respectively.

\subsection{Uncertainty Analysis}

Assuming the glacier/lake boundary passed through the center of each pixel, we computed the uncertainty of glacier/lake $\left(\delta_{\text {area }}\right)$ based on the image spatial resolution and the length of the glacier/lake boundary [42]. The computation formula is

$$
\delta_{\text {area }}=\frac{1}{2} \times l \times r
$$

where $l$ is the length of the glacier/lake boundary and $r$ is the image resolution.

The uncertainty of the average glacier elevation $\left(\delta_{\text {average }}\right)$ was calculated on the basis of the uncertainty of the elevation difference over stable regions and the spatial autocorrection of the elevation difference $[7,43]$. The computation formula is

$$
\delta_{\text {average }}=N M A D \cdot \sqrt{\frac{\pi d^{2}}{5 A}}
$$

where NMAD is calculated by Formula (6), $A$ is the observed glacier area and $d$ is the spatial autocorrection distance of elevation difference in the stable area. In this study, we assumed that the spatial correlation was 30 pixels, namely $900 \mathrm{~m}$.

For glacier mass density, we adopted $\pm 60 \mathrm{~kg} / \mathrm{m}^{3}$ as the uncertainty. The uncertainty of X-band penetration depth was $\pm 0.48 \mathrm{~m}$, and the uncertainty of the difference of $\mathrm{X}$-band and C-band penetration depths was $\pm 0.17 \mathrm{~m}$. The uncertainty of glacier mass balance was determined through the basic error propagation law. The computation formula is

$$
\delta_{\text {mass }}=\sqrt{\left(\frac{\Delta h \cdot \rho_{\text {glacier }}}{\rho_{\text {water }} \cdot S_{\text {total }}} \cdot \delta_{\text {area }}\right)^{2}+\left(\frac{A \cdot \rho_{\text {glacier }}}{\rho_{\text {water }} \cdot S_{\text {total }}} \cdot \delta_{\text {average }}\right)^{2}+\left(\frac{A \Delta \Delta h}{\rho_{\text {water }} \cdot S_{\text {total }}} \cdot \delta_{\rho_{\text {glacier }}}\right)^{2}}
$$

where $\delta_{\text {mass }}, \delta_{\text {area }}, \delta_{\text {average }}$ and $\delta_{\rho_{\text {glacier }}}$ are the uncertainties of glacier mass balance, glacier area, glacier elevation difference and glacier mass density, respectively; $\Delta h$ is the glacier elevation difference; $A$ is the glacier area; $S_{\text {total }}$ is the total glacier area.

\section{Results and Analysis}

\subsection{Changes in Glacier and Glacial Lake Areas during 1974-2018}

Table 4 shows the areas of glaciers and glacial lakes in 1974, 2000, 2012 and 2018. From 1974 to 2018 , the glacier area shrank by $201.55 \mathrm{~km}^{2}(-0.48 \% / \mathrm{a})$, whereas the glacial lake area expanded by $17.81 \mathrm{~km}^{2}(1.94 \% / \mathrm{a})$. In three consecutive periods, the glacier shrinking rate during the period from 2012 to 2018 was the highest $\left(5.69 \mathrm{~km}^{2} / \mathrm{a}\right)$, and the glacial lake expanding rate from 2000 to 2012 was the highest $\left(0.53 \mathrm{~km}^{2} / \mathrm{a}\right)$. The discrepancy in these changes may be caused by two factors. First, many glacial lakes have reached their maximum extent and are bounded by an abrupt steeping of topography [17]. Second, even though the glacier shrinking rate during the period from 2012 to 2018 was the highest, the glacier mass loss rate during the period from 2000 to 2012 was the highest. We primarily 
studied six large glacial lakes in the Xixabangma massif. The locations of the six glacial lakes are shown in Figure 6. The glacial lakes Guoqiangco and Guoruco were mainly fed by the glaciers Guoluo and Guoluoqiang, respectively. From 1974 to 2018, the glacial lakes Guoqiangco and Guoruco expanded by $0.41 \mathrm{~km}^{2}(8.32 \%)$ and $0.61 \mathrm{~km}^{2}(14.66 \%)$, respectively. Meanwhile, their parent glaciers shrank by $1.49 \mathrm{~km}^{2}(17.37 \%)$ and $1.51 \mathrm{~km}^{2}$ $(10.55 \%)$, respectively. Glacial lakes Gangxico, Galongco and Jialongco also have parent glaciers. However, relative to glacial lakes Guoqiangco and Guoruco, these three glacial lakes expanded much faster. From 1974 to 2018, the areas of Gangxico, Galongco and Jialongco increased by $2.53 \mathrm{~km}^{2}(127.41 \%), 4.22 \mathrm{~km}^{2}(373.45 \%)$ and $0.48 \mathrm{~km}^{2}(436.36 \%)$, respectively, and the area of their parent glaciers decreased by $3.23 \mathrm{~km}^{2}(-56.27 \%), 5.01 \mathrm{~km}^{2}$ $(-25.32 \%)$ and $1.35 \mathrm{~km}^{2}(-23.85 \%)$, respectively. After the year 2000, the glacial lake Galongco expanded at a rate of $0.12 \mathrm{~km}^{2} / \mathrm{a}$, and its parent glacier, Jicongpu, shrank at a rate of $0.14 \mathrm{~km}^{2} / \mathrm{a}$. Both rates are considerable. Glacial lake Kungco does not have a parent glacier. From 1974 to 2018, its area decreased from $2.22 \mathrm{~km}^{2}$ to $1.92 \mathrm{~km}^{2}$, and its shrinking rates after 2000 were even higher than that before 2000.

Table 4. Changes in glacier and glacial lake areas in the Xixabangma massif from 1974 to 2018.

\begin{tabular}{|c|c|c|c|c|c|c|c|c|c|}
\hline \multirow{3}{*}{$\begin{array}{c}\text { Glacier } \\
\text { (GLIMS ID) }\end{array}$} & \multirow{3}{*}{ Glacial Lake } & \multicolumn{8}{|c|}{ Area $\left(\mathbf{k m}^{2}\right)$} \\
\hline & & \multicolumn{2}{|c|}{1974} & \multicolumn{2}{|c|}{2000} & \multicolumn{2}{|c|}{2012} & \multicolumn{2}{|c|}{2018} \\
\hline & & Glacier & Lake & Glacier & Lake & Glacier & Lake & Glacier & Lake \\
\hline $\begin{array}{c}\text { Guoluo } \\
(\text { G085581E28525N) }\end{array}$ & Guoqiangco & $\begin{array}{c}8.58 \\
\pm 0.12\end{array}$ & $\begin{array}{l}4.93 \\
\pm 0.08\end{array}$ & $\begin{array}{l}7.59 \\
\pm 0.37\end{array}$ & $\begin{array}{l}5.07 \\
\pm 0.19\end{array}$ & $\begin{array}{l}7.36 \\
\pm 0.18\end{array}$ & $\begin{array}{c}5.21 \\
\pm 0.10\end{array}$ & $\begin{array}{l}7.09 \\
\pm 0.18\end{array}$ & $\begin{array}{l}5.34 \\
\pm 0.10\end{array}$ \\
\hline $\begin{array}{c}\text { Guoluoqiang } \\
(\text { G085618E28467N) }\end{array}$ & Guoruco & $\begin{array}{l}14.31 \\
\pm 0.15\end{array}$ & $\begin{array}{l}4.16 \\
\pm 0.09\end{array}$ & $\begin{array}{l}13.13 \\
\pm 0.39\end{array}$ & $\begin{array}{l}4.67 \\
\pm 0.22\end{array}$ & $\begin{array}{l}12.93 \\
\pm 0.20\end{array}$ & $\begin{array}{c}4.74 \\
\pm 0.11\end{array}$ & $\begin{array}{l}12.80 \\
\pm 0.21\end{array}$ & $\begin{array}{l}4.77 \\
\pm 0.11\end{array}$ \\
\hline $\begin{array}{c}\text { Reqiang } \\
(\text { G085829E28362N) }\end{array}$ & Gangxico & $\begin{array}{c}5.74 \\
\pm 0.13 \\
\end{array}$ & $\begin{array}{c}1.99 \\
\pm 0.04 \\
\end{array}$ & $\begin{array}{c}4.46 \\
\pm 0.25 \\
\end{array}$ & $\begin{array}{c}3.50 \\
\pm 0.13 \\
\end{array}$ & $\begin{array}{c}3.35 \\
\pm 0.11 \\
\end{array}$ & $\begin{array}{c}4.49 \\
\pm 0.09 \\
\end{array}$ & $\begin{array}{c}2.51 \\
\pm 0.11 \\
\end{array}$ & $\begin{array}{r} \\
4.52 \\
\pm 0.09 \\
\end{array}$ \\
\hline $\begin{array}{c}\text { Jicongpu } \\
(\mathrm{G} 085812 \mathrm{E} 28335 \mathrm{~N})\end{array}$ & Galongco & $\begin{array}{l}19.79 \\
\pm 0.21\end{array}$ & $\begin{array}{l}1.13 \\
\pm 0.03\end{array}$ & $\begin{array}{l}17.28 \\
\pm 0.39\end{array}$ & $\begin{array}{l}3.24 \\
\pm 0.17\end{array}$ & $\begin{array}{l}15.47 \\
\pm 0.19\end{array}$ & $\begin{array}{l}5.05 \\
\pm 0.10\end{array}$ & $\begin{array}{l}14.78 \\
\pm 0.20\end{array}$ & $\begin{array}{l}5.35 \\
\pm 0.11\end{array}$ \\
\hline \multirow[t]{2}{*}{$\begin{array}{c}\text { Lengbugang } \\
\text { (G085834E28194E) }\end{array}$} & Jialongco & $\begin{array}{c}5.66 \\
\pm 0.10\end{array}$ & $\begin{array}{c}0.11 \\
\pm 0.01\end{array}$ & $\begin{array}{c}5.08 \\
\pm 0.19\end{array}$ & $\begin{array}{c}0.20 \\
\pm 0.03\end{array}$ & $\begin{array}{c}4.53 \\
\pm 0.08\end{array}$ & $\begin{array}{c}0.57 \\
\pm 0.03\end{array}$ & $\begin{array}{c}4.31 \\
\pm 0.09\end{array}$ & $\begin{array}{c}0.59 \\
\pm 0.03\end{array}$ \\
\hline & Kungco & - & $\begin{array}{c}2.22 \\
\pm 0.05\end{array}$ & 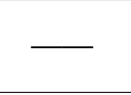 & $\begin{array}{c}2.18 \\
\pm 0.09\end{array}$ & $\longrightarrow$ & $\begin{array}{c}2.04 \\
\pm 0.05\end{array}$ & 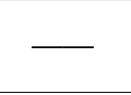 & $\begin{array}{c}1.92 \\
\pm 0.05 \\
\end{array}$ \\
\hline Whole region & Whole region & $\begin{array}{l}954.01 \\
\pm 18.51\end{array}$ & $\begin{array}{l}20.90 \\
\pm 0.81\end{array}$ & $\begin{array}{l}830.03 \\
\pm 43.39\end{array}$ & $\begin{array}{l}30.40 \\
\pm 3.22\end{array}$ & $\begin{array}{l}786.57 \\
\pm 21.22\end{array}$ & $\begin{array}{l}36.70 \\
\pm 1.86\end{array}$ & $\begin{array}{l}752.46 \\
\pm 21.51\end{array}$ & $\begin{array}{l}38.71 \\
\pm 1.93\end{array}$ \\
\hline
\end{tabular}

\subsection{Radar Penetration Depth over Glaciers}

Figure 7a shows the measured X-band penetration depths in different altitude ranges. Over ice-free areas, the X-band penetration depths are close to zero, whereas over glacierized areas, the X-band penetration depths range from $0.15 \mathrm{~m}$ to $5.52 \mathrm{~m}$. The mean values over ice-free and glacierized areas are 0.10 and $3.79 \mathrm{~m}$, respectively. Dehecq et al. [44] measured an average X-band penetration depth of $4 \mathrm{~m}$ at the glacier accumulation zone of the Mont-Blanc area by differencing the Pléiades DEM and TanDEM-X DEM, whereas Lambrecht et al. [45] measured an X-band penetration depth of 3-4 $\mathrm{m}$ at the accumulation zone of the Fedchenko Glacier, Pamir, by differentiating between the GNSS elevation and TanDEM-X elevation. 

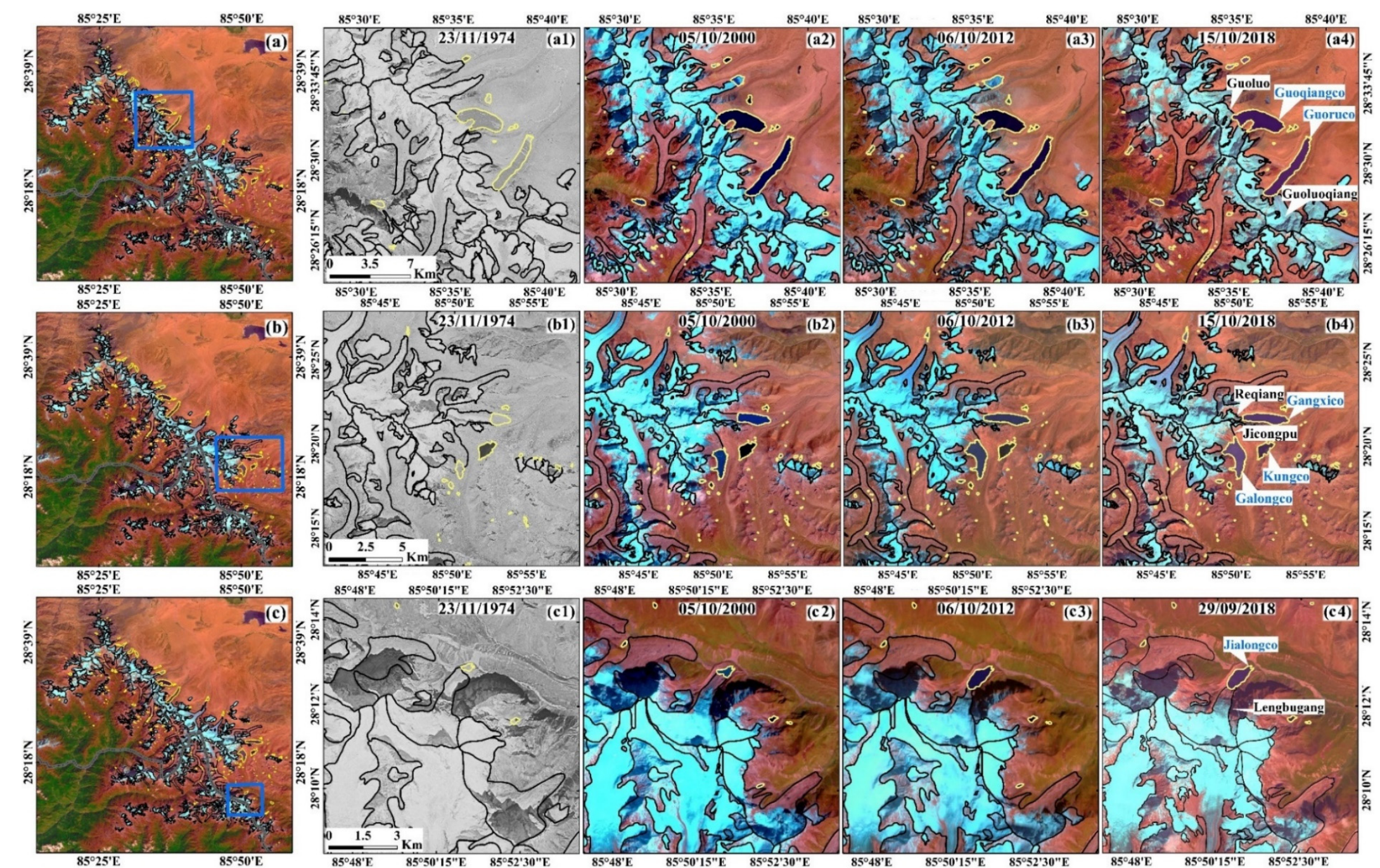

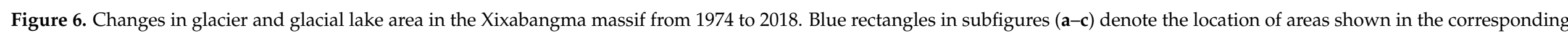

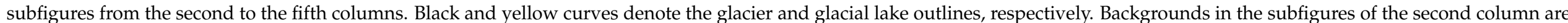
$\mathrm{KH}-9$ images, and those in the rest are Landsat images. 

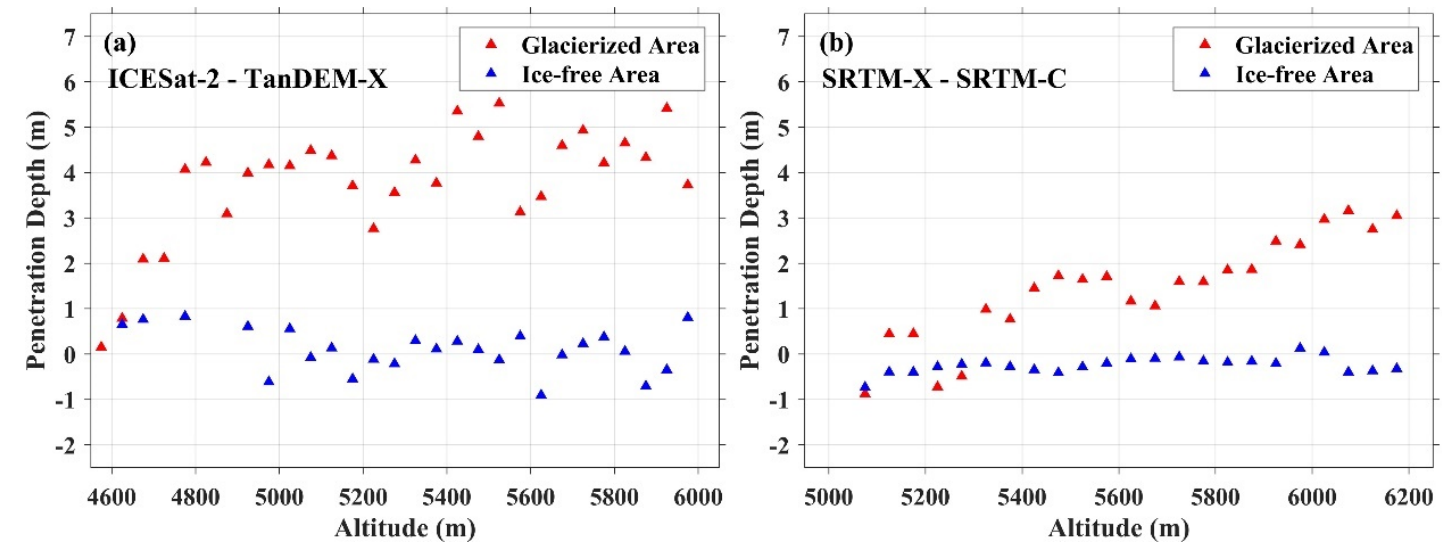

Figure 7. Distribution of measured radar penetration depths against altitude: (a) X-band penetration depth measured by differencing ICESat-2/ ATLAS ATL06 elevations and TanDEM-X elevations. (b) Difference between X-band and C-band penetration depths measured by differencing SRTM-X and SRTM-C DEM.

Figure $7 \mathrm{~b}$ shows the measured differences between $\mathrm{X}$-band and C-band penetration depths. Similarly, over ice-free areas, the penetration depth differences are close to zero, whereas over glacierized areas, the penetration depth differences range from $-0.88 \mathrm{~m}$ to $3.16 \mathrm{~m}$. The mean values over ice-free and glacierized areas are -0.25 and $1.44 \mathrm{~m}$, respectively. Gardelle et al. [22] measured a penetration depth difference of $1.4 \mathrm{~m}$ over the western Nepal glaciers by differencing SRTM-X and SRTM-C DEM, whereas Zhou et al. [46] measured a penetration depth difference of $1.4 \mathrm{~m}$ over the central Nepal glaciers through the same method. The radar penetration depth over glaciers generally in-creases with altitude because colder temperature is generally more suitable for pre-serving fresh snow.

\subsection{Changes in Glacier Thickness and Mass Balance}

The measured region-wide glacier mass balance in the Xixabangma massif was -0.16 $\pm 0.02 \mathrm{~m}$ w.e. / a during the period from 1974 to 2000 (over a glacier area of $605.76 \mathrm{~km}^{2}$ ), $-0.31 \pm 0.03 \mathrm{~m}$ w.e./a during the period from 2000 to 2013 (over a glacier area of $312.38 \mathrm{~km}^{2}$ ) and $-0.29 \pm 0.03 \mathrm{~m}$ w.e./a during the period from 2013 to 2018 (over a glacier area of $187.05 \mathrm{~km}^{2}$ ). Figure 8 shows the measured changes in glacier thickness during three consecutive observation periods (1974-2000, 2000-2013 and 2013-2018). To show the extent of changes in glacier thickness explicitly, we extracted three profiles in three glaciers (Figure 9). For glacier Kangjiaruo (GLIMS ID: G085694E28431N), the largest glacier in the Xixabangma massif, the cumulative thinning during three consecutive periods reached $53.85 \mathrm{~m}, 61.16 \mathrm{~m}$ and $25.65 \mathrm{~m}$. The corresponding annual thinning rates along the profile were $0.93 \mathrm{~m} / \mathrm{a}$, $1.67 \mathrm{~m} / \mathrm{a}$ and $1.22 \mathrm{~m} / \mathrm{a}$ (Profile A). For glacier G085751E28316N, another large glacier that faces the opposite direction, the cumulative thinning during three consecutive periods reached $66.14 \mathrm{~m}, 44.13 \mathrm{~m}$ and $32.59 \mathrm{~m}$, and the corresponding annual thinning rates along the profile were $0.55 \mathrm{~m} / \mathrm{a}, 1.01 \mathrm{~m} / \mathrm{a}$ and $0.57 \mathrm{~m} / \mathrm{a}$ (Profile B). During 1974-2012, glacier Jicongpu (GLIMS ID: G085812E28335N) had the highest receding rate, and its terminus was directly connected to glacial lake Galongco. The glacial lake expanded upward as the glacier terminus retreated. Thus, the lengths of thickness change profiles during three periods vary (Profile $\mathrm{C}$ ). The cumulative thinning of glacier Jicongpu during the first two consecutive periods reached $55.69 \mathrm{~m}$ and $41.06 \mathrm{~m}$, and the corresponding annual thinning rates along the profile were $1.08 \mathrm{~m} / \mathrm{a}$ and $0.99 \mathrm{~m} / \mathrm{a}$. However, the annual thickness change rate along the profile during 2013-2018 was $+0.11 \mathrm{~m} / \mathrm{a}$. As shown in Figure 6, the ablation zone of glacier Jicongpu (GLIMS ID: G085812E28335N) almost vanished before 2012; hence, the observed thickness change rate during 2013-2018 represents a mass change in its accumulation zone. Moreover, glacier Jicongpu had the highest thinning rates. Table 5 lists the average thickness change rates of seven glaciers, including the largest one in the Xixabangma massif and the parent glaciers of the six glacial lakes mentioned above. 


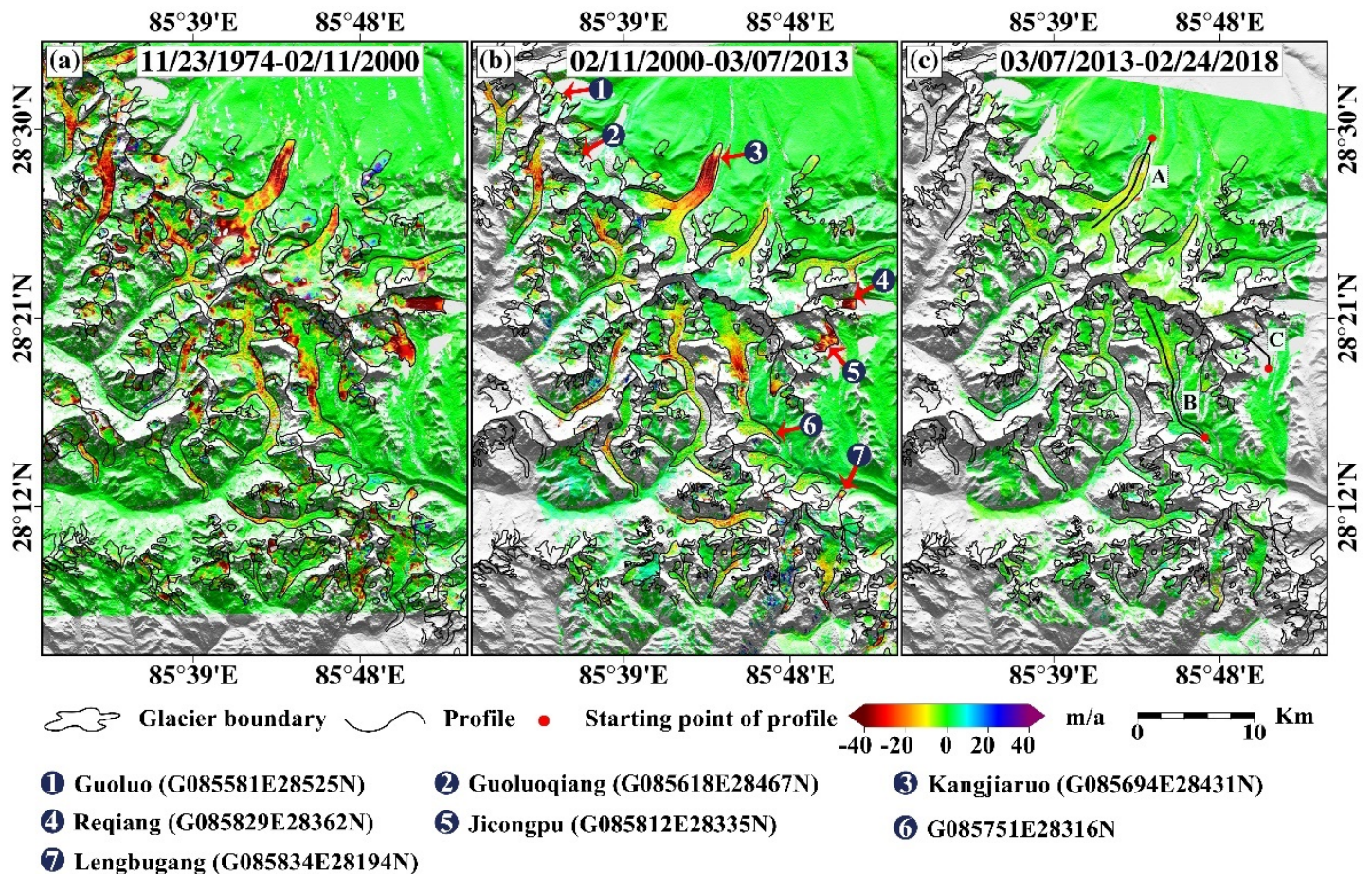

Figure 8. Changes in glacier thickness in the Xixabangma massif during different periods: (a) 02/2000-11/1974 (SRTM-C DEM minus KH-9 DEM); (b) 03/2013-02/2000 (TanDEM-X DEM minus SRTM-C DEM); (c) 02/2018-03/2013 (TanDEM-X DEM minus TanDEM-X DEM). Backgrounds are the shaded SRTM-C DEM. Glacier thickness changes along profiles A, B and $\mathrm{C}$ are shown in Figure 9. The red dots denote the starting points of profiles.
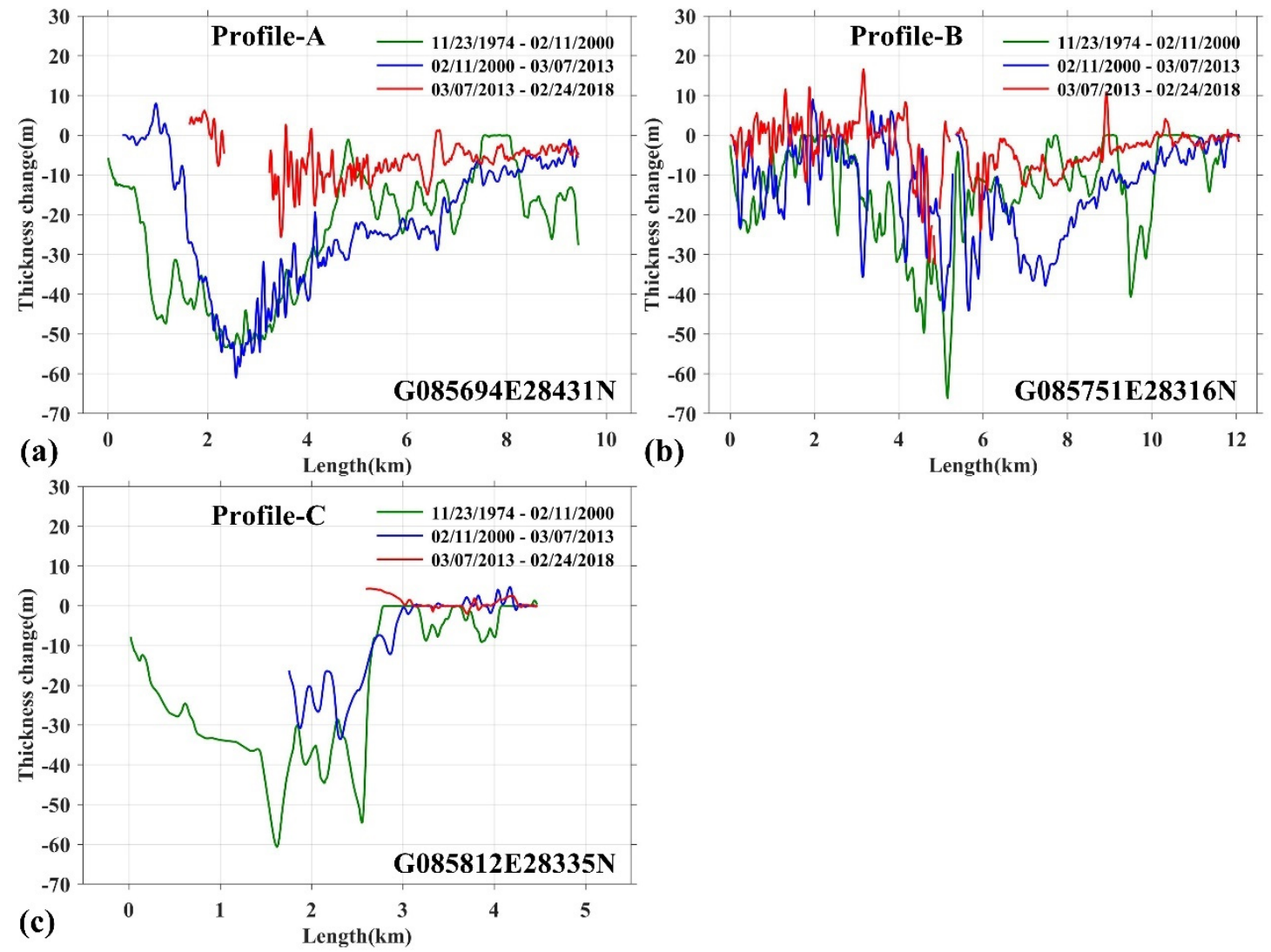

Figure 9. Changes in glacier thickness along three profiles. The location of subfigure $(\mathbf{a}-\mathbf{c})$ is shown in $A, B$ and $C$ of Figure $8 c$, respectively. 
Table 5. Measured thickness changes in seven glaciers in the Xixabangma massif.

\begin{tabular}{cccc}
\hline Glacier Name & \multicolumn{3}{c}{ Thickness Change (m/a) } \\
\cline { 2 - 4 }$($ GLIMS ID) & $\mathbf{1 9 7 4 - 2 0 0 0}$ & $\mathbf{2 0 0 0 - 2 0 1 3}$ & $\mathbf{2 0 1 3 - 2 0 1 8}$ \\
\hline $\begin{array}{c}\text { Kangjiaruo } \\
(\text { G085694E28431N) }\end{array}$ & $-0.57 \pm 0.06$ & $-0.86 \pm 0.04$ & $-0.93 \pm 0.07$ \\
\hline (G085751E28316N) & $-0.28 \pm 0.06$ & $-0.63 \pm 0.04$ & $-0.32 \pm 0.07$ \\
\hline $\begin{array}{c}\text { Reqiang } \\
(\text { G085829E28362N) }\end{array}$ & $-1.09 \pm 0.12$ & $-1.99 \pm 0.13$ & - \\
\hline $\begin{array}{c}\text { Jicongpu } \\
(\text { G085812E28335N) }\end{array}$ & $-0.42 \pm 0.08$ & $-0.95 \pm 0.08$ & $0.12 \pm 0.20$ \\
\hline $\begin{array}{c}\text { Lengbugang } \\
\text { G085834E28194N }\end{array}$ & $-0.12 \pm 0.14$ & $-0.31 \pm 0.12$ & $-0.33 \pm 0.29$ \\
\hline $\begin{array}{c}\text { Guoluoqiang } \\
(\text { G085618E28467N) }\end{array}$ & $-0.05 \pm 0.09$ & $-0.12 \pm 0.08$ & - \\
\hline $\begin{array}{c}\text { Guoluo } \\
(G 085581 E 28525 N)\end{array}$ & $-0.14 \pm 0.12$ & $-0.27 \pm 0.11$ & \\
\hline
\end{tabular}

\section{Discussion}

\subsection{Comparison with Previous Glacier Mass Balance Measurements}

To corroborate the reliability of our glacier mass balance results, we compared them with previously published results that were derived during the same periods. Before our study, Raina et al. [47] (p. 43) reported a mass balance of $-0.16 \mathrm{~m}$ w.e./a from 1979 to 1982 for the Changme Khangpu glacier in the Everest region, as derived by in situ glaciological measurements; Bolch et al. [24] derived a mass balance of $-0.18 \mathrm{~m}$ w.e./a from 1970 to 2007 for the Lhotse Nup glacier in the Everest region based on KH-4B and Cartosat-1 stereo images; Maurer et al. [23] derived a mass balance of $-0.17 \mathrm{~m}$ w.e./a from 1974 to 2006 for glaciers in the Bhutan-China border based on KH-9 and ASTER stereo images. These glacier mass balance results were not affected by radar penetration over glacier surfaces. After removing the effect of C-band penetration, we derived a glacier mass balance of $-0.16 \mathrm{~m}$ w.e./a from 1974 to 2000 , which agreed with above three results. In addition, Pellicciotti et al. [25] derived a mass balance of $-0.32 \mathrm{~m}$ w.e. / a from 1974 to 2000 for glaciers in the Nepal Langtang based on KH-9 stereo images and SRTM-C DEM, and Wu et al. [48] derived a mass balance of -0.24 m w.e./a from 1980 to 2000 for the Kangri Karpo glacier in the Everest region based on topographic maps and SRTM-C DEM. These two studies only removed the effect of relative radar penetration depth, i.e., the difference between X-band and C-band penetration depths. If we used the same method to deal with radar penetration, then a glacier mass balance of $-0.26 \mathrm{~m}$ w.e./a from 1974 to 2000 could be derived; this value is also close to these two results. Furthermore, Kääb et al. [49] derived a mass balance of $-0.30 \mathrm{~m}$ w.e./a from 2003 to 2008 for glaciers in Bhutan and east Nepal based on ICESat-1 elevation products, while Brun et al. [50] derived a mass balance of $-0.31 \mathrm{~m}$ w.e./a from 2003 to 2008 for glaciers in east Nepal based on ICESat-1 elevation products. Our glacier mass balance result during 2000-2013 was $-0.31 \mathrm{~m}$ w.e./a, which agrees with these two results. These horizontal comparisons indicate that our glacier mass balance measurements are reliable.

\subsection{Relationship between Climate Change and Glacier/Glacial Lake Dynamics}

Relative to glacier area and length, glacier mass balance generally responds to climate change more directly. Analyzing the precipitation and temperature data recorded by the Nyalam meteorological station (black triangle in Figure 1), we found that, from 1967 to 2018, the annual average temperature in the Xixabangma massif increased at a rate of $0.23{ }^{\circ} \mathrm{C} / 10 \mathrm{a}$, whereas the annual cumulative precipitation decreased at a rate of $11.4 \mathrm{~mm} / 10 \mathrm{a}$. The 
climate in the Xixabangma massif showed a warming and drying trend over the past half century (Figure 10).

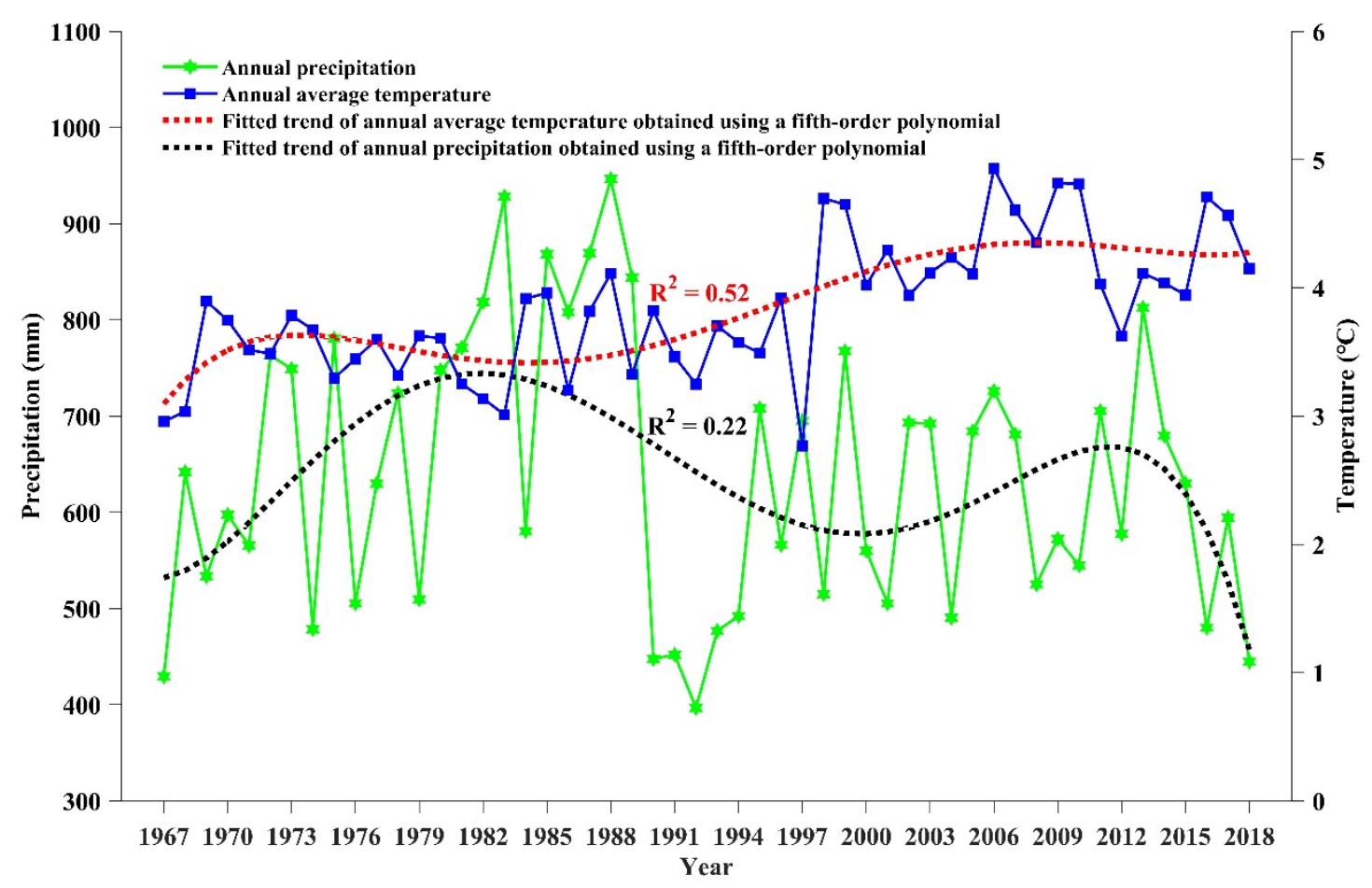

Figure 10. Annual cumulative precipitation and annual average temperature recorded by the Nyalam meteorological station in the Xixabangma massif from 1967 to 2018.

A rise in temperature intensifies glacier ablation, and a decrease in precipitation reduces mass accumulation. The annual average temperatures during the three consecutive glacier mass balance observation periods (1974-1999, 2000-2012 and 2013-2018) were $3.57^{\circ} \mathrm{C}, 4.27^{\circ} \mathrm{C}$ and $4.22{ }^{\circ} \mathrm{C}$, and the corresponding annual cumulative precipitation was $666.5 \mathrm{~mm}, 612.2 \mathrm{~mm}$ and $602.8 \mathrm{~mm}$, respectively. As mentioned above, our glacier mass balance results in the three consecutive periods were $-0.16 \mathrm{~m}$ w.e. $/ \mathrm{a},-0.31 \mathrm{~m}$ w.e. $/ \mathrm{a}$ and $-0.29 \mathrm{~m}$ w.e./a, respectively. In this case, the changing pattern in glacier mass balance aligned with the changing pattern in temperature. This point agrees with that in our previous study [37], i.e., glacier mass balance is more sensitive to changes in temperature than to changes in precipitation.

In this study, the area of lake Kungco that has no water supply from glaciers decreased during the observation period, which is in accordance with the change in precipitation in the Xixabangma massif. By contrast, the area of lakes Guoqiangco, Guoruco, Gangxico, Jialongco and Galongco that have direct water supply from parent glaciers increased. The continuous rise in temperature in the Xixabangma massif may accelerate glacier mass melting and led to an increase in glacial lake water area. Hence, glacier mass balance should be considered a factor in the hazard assessment of glacial lakes [5].

\subsection{Outburst Risk of Major Glacial Lakes in the Xixabangma Massif}

Here, we discuss the outburst risk of six glacial lakes (the specific location is shown in Figure 6) in the Xixabangma massif based on the expanding rates and sizes of lakes, the mass balance of parent glaciers, the state of dams and the distribution of downstream towns.

Glacial lake Kungco is located on the east side of the Xixabangma massif. Its area is $1.92 \mathrm{~km}^{2}$ in 2018. During the three consecutive area observation periods (1974-2000, 2000-2012 and 2012-2018), it shrank by $-1.67 \%,-6.41 \%$ and $-6.12 \%$, respectively. It has no parent glacier, and its shrinking may be related to a lack of precipitation. Moreover, it 
was formed in a nature depression and has no dam. Hence, we deemed that the outburst risk of glacial lake Kungco to be low.

Glacial lakes Guoqiangco and Guoruco were large in size in $2018\left(5.34 \mathrm{~km}^{2}\right.$ and $4.77 \mathrm{~km}^{2}$ ). From 1974 to 2018, they expanded slowly, and their parent glaciers lost mass moderately. In particular, during the three consecutive area observation periods, Guoqiangco expanded by $2.84 \%, 2.76 \%$ and $2.50 \%$, respectively, and Guoruco expanded by $12.26 \%, 1.50 \%$ and $0.63 \%$, respectively. During the first two mass balance observation periods, the mass balance of Guoqiangco's parent glacier, Guoluo, was $-0.12 \mathrm{~m}$ w.e./a and $-0.23 \mathrm{~m}$ w.e./a, respectively, and the corresponding values of Guoruco' parent glacier, Guoluoqiang, were $-0.04 \mathrm{~m}$ w.e. $/ \mathrm{a}$ and $-0.10 \mathrm{~m}$ w.e./a, respectively (the number of observations during 2013 to 2018 was too small). Currently, the dams of these two glacial lakes are about $300 \mathrm{~m}$ wide and formed by solid sediments. These two glacial lakes are located on the north side of the Xixabangma massif and are connected to lake Peikuco by the Naqu river. Towns and infrastructure are absent in the downstream regions. Their impacts on the safety of the residents and social properties are small. Hence, in spite of their large size, we deemed the outburst risk of glacial lakes Guoqiangco and Guoruco to be low.

Glacial lakes Gangxico and Galongco were also large in size in $2018\left(4.52 \mathrm{~km}^{2}\right.$ and $5.35 \mathrm{~km}^{2}$ ). During 1974 to 2018, they expanded quickly, and their parent glaciers lost mass remarkably. In particular, during the three consecutive area observation periods, Gangxico expanded by $75.69 \%, 28.36 \%$ and $0.67 \%$, respectively, and Galongco expanded by $187.07 \%, 55.88 \%$ and $5.98 \%$, respectively. During the first two mass balance observation periods, the mass balance of Gangxico's parent glacier, Reqiang, was $-0.93 \mathrm{~m}$ w.e./a and $-1.69 \mathrm{~m}$ w.e./a., respectively (no observation during 2013 to 2018), and the corresponding values of Galongco's parent glacier, Jicongpu, were $-0.36 \mathrm{~m}$ w.e./a and $-0.80 \mathrm{~m}$ w.e./a, respectively. Note that the mass balance of Jicongpu during the third period seemed to be abnormal because its ablation zone almost melted away at the beginning of this period. Currently, the dams of these two glacial lakes are about $400 \mathrm{~m}$ and $300 \mathrm{~m}$ wide, respectively. Field investigations show that their dams are composed of stagnant ice and moraine [16]. A rise in temperature could cause the ice to melt inside the dam, thus weakening its stability. The downstream drainage channels of these two lakes are directly connected to Nyalam County and the China-Nepal road, one of the main traffic roads between two countries. Moreover, substantial loose debris is found in the downstream drainage channel. The GLOFs can easily create debris flow and cause extensive damage to downstream infrastructures and residential areas. Hence, we deemed that the outburst risk of glacial lakes Gangxico and Galongco to be high.

Glacial lake Jialongco was small in size in $2018\left(0.59 \mathrm{~km}^{2}\right)$. Between 1974 and 2018, it expanded quickly, and its parent glacier, Lengbugang, lost mass remarkably. In particular, during the three consecutive area observation periods, its area increased by $76.58 \%$, $190.82 \%$ and $3.51 \%$, respectively. During the three consecutive mass balance observation periods, the mass balance values of Lengbugang were $-0.10 \mathrm{~m}$ w.e. $/ \mathrm{a},-0.26 \mathrm{~m}$ w.e. $/ \mathrm{a}$ and $-0.28 \mathrm{~m}$ w.e./a, respectively. This glacial lake is located in a high place and the outside slope of its dam is steep. Currently, its dam is about $50 \mathrm{~m}$ wide. Water has already overflowed at the lowest part of the dam and discharge flux has scoured out a shallow channel. The drainage channel of Jialongco is connected to Nyalam County and the distance is much shorter than those found in Gangxico and Galongco. Similarly, there is also much loose debris in the downstream drainage channel, and a lake outburst flood could easily turn into debris flow. Due to strong glacier melting and heavy rainfall, this lake burst twice in 2002, causing severe losses in Nyalam County and on the China-Nepal international road. If temperatures keep rising, we expect more glacial meltwater to enter the lake, and the channel in the dam will enlarge as scouring intensifies; in turn, this may cause the dam to burst again. Hence, we deemed that the outburst risk of lake Jialongco to be very high.

In 1950s and 1960s, when the glacier melting had not been intensified yet, GLOFs also happened in the Himalayas, because external events such as ice collapse, landslide, and heavy rainfall can directly trigger the lake outburst. However, the increase in lake 
water volume caused by the serious glacier mass loss during the recent 20 years aggravated the situation undoubtedly. As the volume of lake water increases, the stability of the lake dam become increasingly susceptible to the external events mentioned above. Besides, as shown in Figure 6, glaciers Lengbugang, Reqiang and Jicongpu significantly retreated after 2000, especially for the latter two, whose terminus directly connect with the glacial lakes. Without buttressing from the lower reaches, the higher reaches of the glaciers will collapse more easily. Furthermore, the Xixabangma massif is located in seismic active zone. Earthquake not only can cause ice collapse and landslides, but also can damage the lake dams directly [28]. In general, glacial lakes Gangxico, Galongco and Jialongco are dangerous and needs special attention.

\subsection{Limitations of This Study}

The water volume of a glacial lake is determined by its area and depth. However, we have no information on lake depth. Given the weak applicability of current area-depth scaling approaches [51], lake depth should be measured for the evaluation of future glacial lake risks. Meanwhile, we analyzed the outburst risk of glacial lakes in a qualitative manner. Compared with quantitative evaluation methods, such as fuzzy consistent matrix [52], event tree [53] and additive ratio scales [54], a qualitative analysis based on multiple factors is somewhat subjective. More rigorous risk evaluation results should be obtained through the use of quantitative methods.

Besides, we have no field data other than meteorological data from one climate station. Given the topographic variation, the data collected by the climate station far away from the glaciers may not accurately characterize the local temperature and precipitation. The glacier debris cover and debris flux also play important roles on regulating glacier ablation. However, we knew little about the characteristics of debris cover in this area, except for the proportion of glacier area covered by debris. Moreover, the interactions between glaciers and proglacial lakes, such as ice front calving, ice erosion by lake water, and glacier debris flux into glacial lakes, can also accelerate the glacier retreat and glacial lake expansion. To find out the holistic cause of changes in glacier and glacial lakes, further exploration of above factors needs to be carried out.

\section{Conclusions}

In this study, we determined changes in glacial lake area, glacier area and glacier mass balance in the Xixabangma massif in different periods. Our results show that the glacier area shrank from $954.01 \mathrm{~km}^{2}$ to $752.46 \mathrm{~km}^{2}$ from 1974 to 2018 , whereas the glacial lake area grew from $20.90 \mathrm{~km}^{2}$ to $38.71 \mathrm{~km}^{2}$. Lacustrine-terminating glaciers retreated faster than land-terminating glaciers. During the periods 1974-2000, 2000-2013 and 2013-2018, the region-wide glacier mass balance values were $-0.16 \mathrm{~m}$ w.e. $/ \mathrm{a},-0.31 \mathrm{~m}$ w.e. $/ \mathrm{a}$ and $-0.29 \mathrm{~m}$ w.e./a, respectively. The annual average temperature during the above three consecutive periods was $3.57{ }^{\circ} \mathrm{C}, 4.27{ }^{\circ} \mathrm{C}$ and $4.22{ }^{\circ} \mathrm{C}$, respectively, indicating a direct response from glacier mass balance to temperature changes. The outburst risk of six glacial lakes was discussed based on the derived changes in lakes and glaciers, as well as other factors. From 1974 to 2018, glacial lakes Gangxico, Galongco and Jialongco expanded by $127.14 \%, 373.45 \%$ and $436.36 \%$, respectively. The mass loss rates of their parent glaciers during 2000-2013 increased by $81.72 \%, 122.22 \%$ and $160.00 \%$ relative to losses from 1974 to 2000. We deemed that the outburst risk of glacial lakes Gangxico, Galongco and Jialongco to be high. By contrast, the outburst risk of the other three glacial lakes, Guoqiangco, Guoruco and Kungco, was considered to be low; these latter three lakes pose no threat to local residents and social property.

Priority should be given to detailed field investigations of glacial lakes Gangxico, Galongco and Jialongco, especially regarding the water depth and the distribution of ice cores in lake dams, both of which are difficult to obtain using remote sensing techniques. The terminal condition and water volume of these three glacial lakes should be monitored regularly, and assumptions concerning their risk should be evaluated periodically. Mean- 
while, it is necessary to install early warning systems for GLOF around high-risk glacial lakes. Enough evacuation time is vital for the purpose of disaster mitigation.

Author Contributions: Conceptualization, J.L. and Y.W.; methodology, J.L., Y.W. and X.Z.; validation, L.G.; formal analysis, J.L. and Y.W.; resources, J.L. and L.W.; data curation, Y.W.; writing-original draft preparation, Y.W.; writing-review and editing, J.L. and L.W.; visualization, Y.W., J.L. and L.G.; supervision, J.L. and L.W.; project administration, J.L., L.W. and Y.W.; funding acquisition, J.L., L.W., J.H. and Y.W. All authors have read and agreed to the published version of the manuscript.

Funding: This work was supported by the Strategic Priority Research Program of Chinese Academy of Sciences (No. XDA20100101), the National Natural Science Foundation of China (No. 41904006), the Hunan Provincial Natural Science Foundation of China (No. 2019JJ50761), the National Key R \& D plans of China (Nos. 2018YFA0605504 and 2018YFC15033600), the Hunan Provincial Talents Gathering Program of China (No. 2018RS3013), the Innovation-Driven Plan of Central South University (Nos. 2019CX007 and 2020CX036), the Fundamental Research Funds for the Central Universities of Central South University (2019zzts637) and the Innovation Foundation of Shanghai Academy of Spaceflight Technology (No. SAST2018-042).

Data Availability Statement: Not applicable.

Acknowledgments: The authors thank below institutions for providing materials for this study. Landsat images, SRTM-C DEM and KH-9 stereo images were from USGS (https: / / earthexplorer.usgs.gov /). ICESat-2/ATLAS ATL06 laser altimetry data were from the US National Snow and ice Data Center (https://nsidc.org/data). TanDEM-X CoSSC images (via Data Project No. jiali_XTI_GLAC6767), and SRTM-X DEM were from DLR (https:/ / eoweb.dlr.de/egp/). Daily climate data were from China Meteorological Data Service Center (http:/ / data.cma.cn/).

Conflicts of Interest: The authors declare no conflict of interest.

\section{References}

1. Berthier, E.; Arnaud, Y.; Kumar, R.; Ahmad, S.; Wagnon, P.; Chevallier, P. Remote sensing estimates of glacier mass balances in the Himachal Pradesh (Western Himalaya, India). Remote Sens. Environ. 2007, 108, 327-338. [CrossRef]

2. Bhushan, S.; Syed, T.H.; Kulkarni, A.V.; Gantayat, P.; Agarwal, V. Quantifying changes in the Gangotri glacier of central Himalaya: Evidence for increasing mass loss and decreasing velocity. IEEE J. Sel. Top. Appl. Earth Obs. Remote Sens. 2017, 10, 5295-5306. [CrossRef]

3. Immerzeel, W.W.; Lutz, A.F.; Andrade, M.; Bahl, A.; Biemans, H.; Bolch, T.; Hyde, S.; Brumby, S.; Davies, B.; Elmore, A.C.; et al. Importance and vulnerability of the world's water towers. Nature 2020, 577, 364-369. [CrossRef]

4. King, O.; Quincey, D.J.; Carrivick, J.L.; Rowan, A.V. Spatial variability in mass loss of glaciers in the Everest region, central Himalayas, between 2000 and 2015. Cryosphere 2017, 11, 407-426. [CrossRef]

5. Fischer, M.; Korup, O.; Veh, G.; Walz, A. Controls of outbursts of moraine-dammed lakes in the greater Himalayan region. Cryosphere Discuss. 2020, 2020, 1-32.

6. Rivera, A.; Casassa, G.; Bamber, J.; Kääb, A. Ice-elevation changes of Glaciar Chico, southern Patagonia, using ASTER DEMs, aerial photographs and GPS data. J. Glaciol. 2005, 51, 105-112. [CrossRef]

7. Rolstad, C.; Haug, T.; Denby, B. Spatially integrated geodetic glacier mass balance and its uncertainty based on geostatistical analysis: Application to the western Svartisen ice cap, Norway. J. Glaciol. 2009, 55, 666-680. [CrossRef]

8. Matsuo, K.; Heki, K. Time-variable ice loss in Asian high mountains from satellite gravimetry. Earth Planet. Sci. Lett. 2010, 290, 30-36. [CrossRef]

9. Bolch, T.; Kulkarni, A.; Kääb, A.; Huggel, C.; Paul, F.; Cogley, J.G.; Frey, H.; Kargel, J.S.; Fujita, K.; Scheel, M.; et al. The state and fate of Himalayan glaciers. Science 2012, 336, 310-314. [CrossRef]

10. Akhtar, M.; Ahmad, N.; Booij, M. The impact of climate change on the water resources of Hindukush-Karakorum-Himalaya region under different glacier coverage scenarios. J. Hydrol. 2008, 355, 148-163. [CrossRef]

11. Scherler, D.; Bookhagen, B.; Strecker, M.R. Spatially variable response of Himalayan glaciers to climate change affected by debris cover. Nat. Geosci. 2011, 4, 156-159. [CrossRef]

12. Rowan, A.V.; Egholm, D.L.; Quincey, D.J.; Glasser, N.F. Modelling the feedbacks between mass balance, ice flow and debris transport to predict the response to climate change of debris-covered glaciers in the Himalaya. Earth Planet. Sci. Lett. 2015, 430, 427-438. [CrossRef]

13. King, O.; Bhattacharya, A.; Bhambri, R.; Bolch, T. Glacial lakes exacerbate Himalayan glacier mass loss. Sci. Rep. 2019, 9, 1-9. [CrossRef]

14. Nie, Y.; Liu, Q.; Wang, J.; Zhang, Y.; Sheng, Y.; Liu, S. An inventory of historical glacial lake outburst floods in the Himalayas based on remote sensing observations and geomorphological analysis. Geomorphology 2018, 308, 91-106. [CrossRef] 
15. Chen, X.-Q.; Cui, P.; Li, Y.; Yang, Z.; Qi, Y.-Q. Changes in glacial lakes and glaciers of post-1986 in the Poiqu River basin, Nyalam, Xizang (Tibet). Geomorphology 2007, 88, 298-311. [CrossRef]

16. Shijin, W.; Shitai, J. Evolution and outburst risk analysis of moraine-dammed lakes in the central Chinese Himalaya. J. Earth Syst. Sci. 2015, 124, 567-576. [CrossRef]

17. Zhang, G.; Bolch, T.; Allen, S.; Linsbauer, A.; Chen, W.; Wang, W. Glacial lake evolution and glacier-lake interactions in the Poiqu River basin, central Himalaya, 1964-2017. J. Glaciol. 2019, 65, 347-365. [CrossRef]

18. Vincent, C.; Ramanathan, A.; Wagnon, P.; Dobhal, D.P.; Linda, A.; Berthier, E.; Sharma, P.; Arnaud, Y.; Azam, M.F.; Jose, P.G.; et al. Balanced conditions or slight mass gain of glaciers in the Lahaul and Spiti region (northern India, Himalaya) during the nineties preceded recent mass loss. Cryosphere 2013, 7, 569-582. [CrossRef]

19. Azam, M.F.; Ramanathan, A.; Wagnon, P.; Vincent, C.; Linda, A.; Berthier, E.; Sharma, P.; Mandal, A.; Angchuk, T.; Singh, V.; et al Meteorological conditions, seasonal and annual mass balances of Chhota Shigri Glacier, western Himalaya, India. Ann. Glaciol. 2016, 57, 328-338. [CrossRef]

20. Vijay, S.; Braun, M. Elevation change rates of glaciers in the Lahaul-Spiti (Western Himalaya, India) during 2000-2012 and 2012-2013. Remote Sens. 2016, 8, 1038. [CrossRef]

21. Mukherjee, K.; Bhattacharya, A.; Pieczonka, T.; Ghosh, S.; Bolch, T. Glacier mass budget and climate reanalysis data indicate a climatic shift around 2000 in Lahaul-Spiti, western Himalaya. Clim. Chang. 2018, 148, 219-233. [CrossRef]

22. Gardelle, J.; Berthier, E.; Arnaud, Y.; Kääb, A. Region-wide glacier mass balances over the Pamir-Karakoram-Himalaya during 1999-2011. Cryosphere 2013, 7, 1263-1286. [CrossRef]

23. Maurer, J.M.; Rupper, S.B.; Schaefer, J.M. Quantifying ice loss in the eastern Himalayas since 1974 using declassified spy satellite imagery. Cryosphere 2016, 10, 2203-2215. [CrossRef]

24. Bolch, T.; Pieczonka, T.; Benn, D.I. Multi-decadal mass loss of glaciers in the Everest area (Nepal Himalaya) derived from stereo imagery. Cryosphere 2011, 5, 349-358. [CrossRef]

25. Pellicciotti, F.; Stephan, C.; Miles, E.; Herreid, S.; Immerzeel, W.W.; Bolch, T. Mass-balance changes of the debris-covered glaciers in the Langtang Himal, Nepal, from 1974 to 1999. J. Glaciol. 2015, 61, 373-386. [CrossRef]

26. Lamsal, D.; Fujita, K.; Sakai, A. Surface lowering of the debris-covered area of Kanchenjunga Glacier in the eastern Nepal Himalaya since 1975, as revealed by Hexagon KH-9 and ALOS satellite observations. Cryosphere 2017, 11, 2815-2827. [CrossRef]

27. Chen, X.; Cui, P.; Yang., Z.; Qi, Y. Debris flows of Chongdui Gully in Nyalam County, 2002: Cause and control. J. Glaciol. Geocryol. 2006, 28, 776-781. (In Chinese)

28. Kargel, J.S.; Leonard, G.J.; Shugar, D.H.; Haritashya, U.K.; Bevington, A.; Fielding, E.J.; Fujita, K.; Geertsema, M.; Miles, E.S.; Steiner, J.; et al. Geomorphic and geologic controls of geohazards induced by Nepals 2015 Gorkha earthquake. Science 2015, 351, aac8353. [CrossRef]

29. Surazakov, A.; Aizen, V. Positional accuracy evaluation of declassified hexagon KH-9 mapping camera imagery. Photogramm. Eng. Remote. Sens. 2010, 76, 603-608. [CrossRef]

30. Zhang, X.; Zhou, J.; Liu, Z. DEM extraction and precision evaluation of mountain glaciers in the Qinghai-Tibet Plateau based on KH-data: Take the Purog Kangri Glacier and the Jiong Glacier as example. J. Glaciol. Geocryol. 2019, 41, 27-35. (In Chinese)

31. Pieczonka, T.; Bolch, T.; Junfeng, W.; Shiyin, L. Heterogeneous mass loss of glaciers in the Aksu-Tarim Catchment (Central Tien Shan) revealed by 1976 KH-9 hexagon and 2009 SPOT-5 stereo imagery. Remote Sens. Environ. 2013, 130, 233-244. [CrossRef]

32. Wang, Y.; Li, J.; Wu, L.; Guo, L.; Li, J. Using remote sensing images to monitor the glacier changes in Qilian Mountains during 1987-2018 and analyzing the impact factors. J. Glaciol. Geocryol. 2020, 42, 344-356. (In Chinese)

33. Andreassen, L.M.; Paul, F.; Kääb, A.; Hausberg, J.E. Landsat-derived glacier inventory for Jotunheimen, Norway, and deduced glacier changes since the 1930s. Cryosphere 2008, 2, 131-145. [CrossRef]

34. Kwok, R.; Cunningham, G.F.; Zwally, H.J.; Yi, D. ICESat over Arctic sea ice: Interpretation of altimetric and reflectivity profiles. J. Geophys. Res. Oceans 2006, 111, C06006. [CrossRef]

35. Smith, B.; Fricker, H.A.; Holschuh, N.; Gardner, A.; Adusumilli, S.; Brunt, K.M.; Csatho, B.; Harbeck, K.; Huth, A.; Neumann, T.; et al. Land ice height-retrieval algorithm for NASA's ICESat-2 photon-counting laser altimeter. Remote Sens. Environ. 2019, 233, 111352. [CrossRef]

36. Nuth, C.; Kääb, A. Co-registration and bias corrections of satellite elevation data sets for quantifying glacier thickness change. Cryosphere 2011, 5, 271-290. [CrossRef]

37. Li, Z.-W.; Li, J.; Ding, X.-L.; Wu, L.; Ke, L.-H.; Hu, J.; Xu, B.; Peng, F. Anomalous glacier changes in the southeast of Tuomuer-khan Tengri Mountain ranges, central Tianshan. J. Geophys. Res. Atmos. 2018, 123, 6840-6863. [CrossRef]

38. Berthier, E.; Arnaud, Y.; Baratoux, D.; Vincent, C.; Rémy, F. Recent rapid thinning of the "Mer de Glace" glacier derived from satellite optical images. Geophys. Res. Lett. 2004, 31, L17401. [CrossRef]

39. Guo, L.; Li, J.; Wu, L.; Li, Z.; Liu, Y.; Li, X.; Miao, Z.; Wang, W. Investigating the recent surge in the Monomah Glacier, Central Kunlun Mountain range with multiple sources of remote sensing data. Remote Sens. 2020, 12, 966. [CrossRef]

40. Höhle, J.; Höhle, M. Accuracy assessment of digital elevation models by means of robust statistical methods. ISPRS J. Photogramm. Remote Sens. 2009, 64, 398-406. [CrossRef]

41. Huss, M. Density assumptions for converting geodetic glacier volume change to mass change. Cryosphere 2013, 7, 877-887. [CrossRef] 
42. Fujita, K.; Sakai, A.; Nuimura, T.; Yamaguchi, S.; Sharma, R.R. Recent changes in Imja Glacial Lake and its damming moraine in the Nepal Himalaya revealed by in situ surveys and multi-temporal ASTER imagery. Environ. Res. Lett. 2009, 4, 045205. [CrossRef]

43. Li, J.; Li, Z.-W.; Hu, J.; Wu, L.-X.; Li, X.; Guo, L.; Liu, Z.; Miao, Z.-L.; Wang, W.; Chen, J.-L. Investigating the bias of TanDEM-X digital elevation models of glaciers on the Tibetan Plateau: Impacting factors and potential effects on geodetic mass-balance measurements. J. Glaciol. 2021, 2021, 1-14. [CrossRef]

44. Dehecq, A.; Millan, R.; Berthier, E.; Gourmelen, N.; Trouve, E.; Vionnet, V. Elevation changes inferred from TanDEM-X data over the Mont-Blanc area: Impact of the X-band interferometric bias. IEEE J. Sel. Top. Appl. Earth Obs. Remote Sens. 2016, 9, 3870-3882. [CrossRef]

45. Lambrecht, A.; Mayer, C.; Wendt, A.; Floricioiu, D.; Völksen, C. Elevation change of Fedchenko Glacier, Pamir Mountains, from GNSS field measurements and TanDEM-X elevation models, with a focus on the upper glacier. J. Glaciol. 2018, 64, 637-648. [CrossRef]

46. Zhou, Y.; Li, Z.; Li, J.; Zhao, R.; Ding, X. Glacier mass balance in the Qinghai-Tibet Plateau and its surroundings from the mid-1970s to 2000 based on Hexagon KH-9 and SRTM DEMs. Remote Sens. Environ. 2018, 210, 96-112. [CrossRef]

47. Raina, V.K. Himalayan Glaciers: A State-Of-Art Review of Glacial Studies, Glacial Retreat and Climate Change; Ministry of Environment and Forests, Government of India: New Delhi, India, 2009; p. 43.

48. Wu, K.; Liu, S.; Jiang, Z.; Xu, J.; Wei, J.; Guo, W. Recent glacier mass balance and area changes in the Kangri Karpo Mountains from DEMs and glacier inventories. Cryosphere 2018, 12, 103-121. [CrossRef]

49. Kääb, A.; Berthier, E.; Nuth, C.; Gardelle, J.; Arnaud, Y. Contrasting patterns of early twenty-first-century glacier mass change in the Himalayas. Nature 2012, 488, 495-498. [CrossRef]

50. Brun, F.; Berthier, E.; Wagnon, P.; Kääb, A.; Treichler, D. A spatially resolved estimate of High Mountain Asia glacier mass balances from 2000 to 2016. Nat. Geosci. 2017, 10, 668-673. [CrossRef]

51. Veettil, B.K.; Kamp, U. Glacial lakes in the Andes under a changing climate: A review. J. Earth Sci. 2021, 32, 1-19. [CrossRef]

52. Wang, W.; Yao, T.; Gao, Y.; Yang, X.; Kattel, D.B. A first-order method to identify potentially dangerous glacial lakes in a region of the Southeastern Tibetan Plateau. Mt. Res. Dev. 2011, 31, 122. [CrossRef]

53. Wang, X.; Liu, S.; Ding, Y.; Guo, W.; Jiang, Z.; Lin, J.; Han, Y. An approach for estimating the breach probabilities of morainedammed lakes in the Chinese Himalayas using remote-sensing data. Nat. Hazards Earth Syst. Sci. 2012, 12, 3109-3122. [CrossRef]

54. Bolch, T.; Peters, J.; Yegorov, A.; Pradhan, B.; Buchroithner, M.; Blagoveshchensky, V. Identification of potentially dangerous glacial lakes in the northern Tien Shan. Nat. Hazards 2011, 59, 1691-1714. [CrossRef] 